\title{
An Experimental Study on Eco-Friendly and Cost- Effective Natural Materials for Productivity Enhancemento Single Slope Solar Still
}

SENDHIL KUMAR NATARAJAN ( $\sim$ drsendhil1980iitmuk@gmail.com )

National Institute of Technology Puducherry https://orcid.org/0000-0003-3257-4570

Subbarama Kousik Suraparaju

NIT Puducherry: National Institute of Technology Puducherry

Rajvikram Madurai Elavarasan

Texas A\&M University College Station: Texas A\&M University

Rishi Pugazhendhi

Sri Venkateswara College of Engineering

Eklas Hossain

Oregon Institute of Technology

\section{Research Article}

Keywords: Solar Still, Sawdust, Rice Straw, Evaporation, Condensation, Productivity Enhancement.

Posted Date: June 24th, 2021

DOl: https://doi.org/10.21203/rs.3.rs-609138/v1

License: (c) (i) This work is licensed under a Creative Commons Attribution 4.0 International License. Read Full License

Version of Record: A version of this preprint was published at Environmental Science and Pollution Research on August 6th, 2021. See the published version at https://doi.org/10.1007/s11356-021-157648. 
3 Sendhil Kumar Natarajan(0000-0003-3257-4570) 1*, Subbarama Kousik Suraparaju (0000-0002-4193-7380) 1, Rajvikram 4 Madurai Elavarasan ${ }^{(0000-0003-1639-2953)}$, , Rishi Pugazhendhi ${ }^{(0000-0001-6831-6288) 3}$, Eklas Hossain ${ }^{(0000-0003-2332-8095) 4}$

$5{ }^{1}$ Solar Energy Laboratory, Department of Mechanical Engineering, National Institute of Technology

6 Puducherry,Karaikal, Union Territoryof Puducherry, - 609609, India.

$7 \quad{ }^{2}{ }^{2}$ Clean and Resilient Energy Systems (CARES) Laboratory, Texas A\&M University, Galveston, TX 8 77553,USA.

$9 \quad 3 \quad{ }^{3}$ Department of Mechanical Engineering, Sri Venkateswara College of Engineering, Chennai 602117, India.

$10{ }^{4}$ Department of Electrical Engineering and Renewable Energy, Oregon Institute of Technology, Klamath Falls,

11 OR 97601, USA.

Email ID: drsendhil1980iitmuk@gmail.com orsendhil80@nitpy.ac.in (S.K. Natarajan), s.s.r.kousik@hotmail.com (S.K. Suraparaju), rajvikram787@gmail.com (R.M. Elavarasan), rishi2000.p@gmail.com (R. Pugazhendhi), eklas.hossain@oit.edu (E. Hossain) 


\section{Abstract}

13 The proposed research study aims to improve the productivity of solar still (SS) by using low-cost and eco-

14 friendly materials. The aforementioned objective was achieved by enhancing the evaporation rate of seawater in 15 the absorber basin and the condensation rate over the glass cover of the solar still. In this study, the low-cost and 16 eco-friendly materials used for enhancing the evaporation rate in the solar still were Molasses Powder (MP), 17 Sawdust (SD), Rise Husk (RH). In addition to these materials, Bamboo Straw (BS), Banana Leaf stem (BL), and 18 Rice Straw (RS) were used as absorbing materials over the glass cover for enhancing the condensation rate. The 19 experiments were carried out under similar meteorological conditions and the results of the modified solar still 20 were compared with Conventional Solar Still (CSS). The productivities of CSS, SSMP, SSRH, SSSD, SSBS, 21 SSBL and SSRS were about $2250 \mathrm{~mL} / \mathrm{m}^{2}, 2383 \mathrm{~mL} / \mathrm{m}^{2}, 2467 \mathrm{~mL} / \mathrm{m}^{2}, 3033 \mathrm{~mL} / \mathrm{m}^{2}, 2700 \mathrm{~mL} / \mathrm{m}^{2}, 2683 \mathrm{~mL} / \mathrm{m}^{2}$, 22 and $3367 \mathrm{~mL} / \mathrm{m}^{2}$, respectively. The results of the experimental investigation highlighted that the SSSD had a 23 comparatively better evaporation rate and $34.81 \%$ higher yield than CSS. Besides, SSRS had a comparatively 24 better condensation rate and a 51.88\% higher yield than CSS. Later, the combination of sawdust (SD) and rice straw (RS) was investigated for combined enhancement of evaporation and condensation. The solar still with sawdust and rice straw (SSSDRS) showed a $62.88 \%$ improvement in productivity with $3633 \mathrm{~mL} / \mathrm{m}^{2}$ when compared to CSS. Also, the economic analysis showed that the cost per litre (CPL) of freshwater obtained from SSSDRS was about ₹ $1.9(\$ 0.025)$ with a payback period of 4.4 months which was the least when compared to all the considered cases.

30 Keywords: Solar Still; Sawdust; Rice Straw; Evaporation; Condensation; Productivity Enhancement.

\section{$31 \quad$ Highlights}

- The performance of solar still was examined with low-cost and eco-friendly materials.

- SSSD had a better evaporation rate and enhanced yield by $34.81 \%$.

- SSRS had a better condensation rate and enhanced yield by $51.88 \%$.

- SSSDRS enhanced evaporation and condensation rates with a $62.88 \%$ increase in yield.

- Cost/litre and Pay Back Period of SSSDRS were ₹1.9 and 4.4 months, respectively. 


\section{Introduction}

38 The freshwater demand has been rapidly increasing across the world by about $1 \%$ since the 1980 s due to industrialization, urbanization, modernization in agricultural practices and growth in the population. It has been estimated that more than 2 billion people are living in water stress areas and over 4 billion people in the world are facing water scarcity at least for a month during a year. Further, climate change may affect the accessibility, quality and quantity of freshwater resources on the earth. In this situation, the recognition of water resources, safeguarding the water resources and valuing the water has become the primary goal to overcome the water stress/scarcity across the globe. A plausible solution to overcome this problem is to convert the available seawater into freshwater through desalination approaches. The energy required for driving the desalination process is another concern that is to be addressed immediately. The utilization of conventional energy sources in the current situation is not recommendable since global warming and depletion of energy sources are the other alarming glitches to the world along with freshwater scarcity. Hence, the desalination approach driven by renewable energy sources is the best possible way to address the global freshwater and energy demands.

In the availableseawater desalination approaches, solar still is considered as one of the economical and sustainable ways of desalination. Also, the solar still have been successful in desalinating not only seawater but also the industrial effluents, reverse osmosis reject and sewage water (Velmurugan et al. 2008a, 2009; Reddy et al. 2018; Sleiti et al. 2021). Solar still is an economical and environmentally friendly desalination approach since it utilises solar energy for its operation which is abundant and thereby, reducing the energy-related costs. Also, the utilization of solar energy for desalinating the seawater reduces the carbon footprint. The solar still is simple in its construction with a fewer number of components compared to other desalination approaches (Thirugnanasambandam et al. 2010; Sharon and Reddy 2015; Xevgenos et al. 2016). However, the efficiency of conventional solar still is comparatively less $(\sim 20-30 \%)$. This opens up a wide opportunity for improvising the productivity of the solar still. Typically, the efficiency or the productivity of the solar still can be enhanced by increasing the evaporation and condensation rate. The evaporation rate is commonly improved by decreasing the humidity and increasing the temperature. A warmer environment creates a dry ambience inside the solar still which will increase the water vapour carrying capacity of air. Several other parameters to be considered for increasing the evaporation rate include absorption rate of basin water and still basin, the volumetric heat capacity of the basin, water depth, inlet temperature of the basin and the temperature of the surface of the water (Muthu Manokar et al. 2014). On the other hand, the condensation rate can be enhanced by lowering the temperature of condensing plate and by 
increasing the convective heat transfer rate (from condensing plate to surroundings)(Muthu Manokar et al. 2014; Prakash and Velmurugan 2015). This will decrease the water vapour carrying capacity of the surrounding air and in turn droplets of water will be condensed. Many kinds of research are focusing on several approaches to enhance the productivity of solar still which is discussed in Section 2. Such approaches mainly concentrate on increasing the evaporation and condensation rates via different design of solar stills, incorporating energy storage components, and by enhancing the heat transfer rates. However, a simple yet effective means of productivity enhancement is far from reality. In context, this study is propounded to analyse the influence of eco-friendly and cost-effective materials for enhancing the productivity of solar still. Section 2 emphasize various existing methods and recent researches involved in solar still. Section 3 provides deep insight into the materials utilized and the experimentation. Section 4 presents the thermal and economic analysis associated with this research. Section 5 highlights the results and conclusions are drawn in Section 6.

\section{Literature Review}

Many researchers across the world are working to improve the efficacy of solar still through several modifications in the system design and incorporations such as fins/energy storage, nanofluids and nanomaterials into the still and glass cooling techniques to enhance the condensation rate(Al-Nimr and Al-Ammari 2016; Kabeel et al. 2019b; Patel and Modi 2020; Sleiti et al. 2020). This section is dedicated to elaborate on the various approaches in enhancing the productivity of the solar still.

\subsection{The role of design parameters in productivity enhancement}

(Tripathi and Tiwari 2005; Tiwari and Tiwari 2006) assessed the effect of water depth in the still on heat and mass transfer. The investigation results showed that the internal heat and mass transfer is substantially influenced by the depth of water in the still. It is observed that as the depth of water increases, the lower water temperature has resulted which in turn decreases the convective heat transfer coefficient. (Akash et al. 2000) investigated the effect of the tilt angle of glass cover on the productivity of solar still under Jordan city climatic conditions. It was observed that the solar still with a $35^{\circ}$ tilt angle ( equal to the latitude of Jordan) had better productivity when compared to the other tilt angles such as $15^{\circ}, 25^{\circ}, 45^{\circ}$ and $55^{\circ}$.(Khalifa and Hamood 2009) analysed the influence of insulation thickness on the freshwater productivity of solar still. It was noticed that an increase in the thickness of insulation results in increased productivity and the thickness of insulation influenced productivity by over $80 \%$. (Nagarajan et al. 2017) studied the influence of baffles on the productivity of solar still. It was found that the solar still with baffles had productivity of $5.4 \mathrm{~kg} / \mathrm{m}^{2}$ whereas the solar still without baffles had productivity of $3.4 \mathrm{~kg} / \mathrm{m}^{2}$ per day.(Tabrizi et al. 2010) studied the weir type cascade solar still for 
enhancing the distillate yield. It was found that the flow of inlet water substantially decreased the productivity of solar still as influenced by a reduction in the internal heat and mass transfer rates. The productivity of solar still was about $7.4 \mathrm{~kg} / \mathrm{m}^{2}$ and $4.3 \mathrm{~kg} / \mathrm{m}^{2}$ per day for minimum and maximum flow rates of inlet water.(Dev et al.

100 2011) analysed the effect of inverted absorber on the productivity of solar still. It was noticed that the inverted 101 absorber solar still had productivity of $6.302,5.576$ and $4.299 \mathrm{~kg} / \mathrm{m}^{2} /$ day for the $1 \mathrm{~cm}, 2 \mathrm{~cm}$ and $3 \mathrm{~cm}$ water depths, respectively. Whereas for the same water depths, the traditional solar still had a yield of 2.152, 1.931,

$1030.826 \mathrm{~kg} / \mathrm{m}^{2} /$ day.(Gad et al. 2015) developed and studied the influence of conical solar still on freshwater yield.

104 It was reported that the conical solar still had a yield of $3.38 \mathrm{~L} / \mathrm{m}^{2}$ whereas the conventional solar still had a

105 yield of $1.93 \mathrm{~L} / \mathrm{m}^{2}$. This is primarily attributed due to the higher values of evaporative, convective and radiative

106 heat transfer coefficients during the daytime when compared to conventional solar still. (Attia et al. 2021b)

107 investigated the performance of hemispherical solar still with iron, zinc and copper absorber trays and the results 108 were compared with conventional hemispherical still. The results showed that the hemispherical solar still with 109 copper, zinc and iron absorbers had an improvement in yield by $53.12 \%, 31.25 \%$ and $14.58 \%$, respectively 110 when compared with the productivity of conventional hemispherical solar still.(Saadi et al. 2018) studied the 111 performance of stepped solar still with a multi evaporator tray. It was found that the productivity of stepped 112 solar still had improved productivity of $47.18 \%, 62.73 \%, 94.21 \%$ and $104.73 \%$ for spring, autumn, winter and 113 summer, respectively.

\section{2.2. External collectors and hybrid solar stills for improving evaporation rate}

115 (Sampathkumar et al. 2013) investigated the effect of evacuated tube collector connected to solar still on 116 freshwater productivity. It was observed that the solar still with evacuated tube collector had a yield of $1177.03 \mathrm{~kg} / \mathrm{m}^{2} /$ day whereas the conventional solar still had a yield of $3.225 \mathrm{~kg} / \mathrm{m}^{2} / \mathrm{day}$ at a depth $\mathrm{of} 4 \mathrm{~cm}$. (Kumar et 118 al. 2014) studied the influence of evacuated solar still under forced circulation mode. It was found that the 119 maximum yield obtained from the solar still was about $3.47 \mathrm{~kg}$ for $1 \mathrm{~cm}$ basin water depth with an optimum 120 flow rate of $0.006 \mathrm{~kg} / \mathrm{s}$. (Jafari Mosleh et al. 2015) investigated the effect of solar still with a combination of the 121 heat pipe, evacuated tube and parabolic trough collector on the daily freshwater productivity. It was observed 122 that the modified solar still with aluminium conducting foils as a heat transfer medium had a yield of $0.27 \mathrm{~kg} /$ $123\left(\mathrm{~m}^{2} \mathrm{~h}\right)$ with $22.1 \%$ energy efficiency. Whereas, the solar still with oil as heat transfer medium had a yield of $1240.933 \mathrm{~kg} /\left(\mathrm{m}^{2} \mathrm{~h}\right)$ with $65.2 \%$ energy efficiency.(Kabeel et al. 2019a) studied the performance of solar still 125 integrated with two solar dish concentrators. It was found that the solar still with one solar dish concentrator had 126 a yield of 8.8 and $5.45 \mathrm{~kg} /$ day for $1 \mathrm{~cm}$ and $2 \mathrm{~cm}$ water depths. Whereas, the solar still with two solar dish 
127 concentrators had a yield of 13.63 and $7.69 \mathrm{~kg} /$ day for $1 \mathrm{~cm}$ and $2 \mathrm{~cm}$ water depths, correspondingly. (Manokar

128 et al. 2020) studied the performance of solar still with photovoltaic panel and flat plate collector. It was found

129 that the freshwater yield from the modified solar still was about 7.5, 6.5 and $5.4 \mathrm{~kg}$, and the electrical efficiency

130 was about $7.2 \%, 7.6 \%$ and $8.1 \%$ for $1.8,3.2$ and $4.7 \mathrm{~kg} / \mathrm{h}$ mass flow rates, respectively. The results also indicated

131 that when the mass flow rate is increased, the yield of distillate, overall thermal efficiency is decreased but it

132 increases the PV power production and overall exergy efficiency.(Sharshir et al. 2016) investigated the

133 performance of solar still integrated with humidification - dehumidification (H-DH) desalination system. In this

134 hybrid system, the warm water rejected from the H-DH system serves as feed water for solar still. The

135 productivity of single solar still in the hybrid system was improved by almost $200 \%$ compared to the

136 productivity of CSS.(Shehata et al. 2020) assessed the performance of solar still with energy storage material

137 and ultrasonic humidifiers integrated with evacuated tube collectors. It was observed that the highest

138 productivity was obtained for the case of solar still with energy storage and ultrasonic humidifier integrated with

139 evacuated solar collectors. The maximum productivity obtained from the solar still was about 5.34 and $7.4 \mathrm{~kg}$

140 per day for $2.5 \mathrm{~cm}$ and $3.5 \mathrm{~cm}$ water depths.

\section{2.3. Productivity enhancement by increasing wet surface area}

142 (Velmurugan et al. 2008b) Velmurugan et al. investigated the influence of fins, wick materials and sponges on

143 the productivity of solar still. The results indicated that the solar still with fins, sponges and wicks enhanced

144 productivity by $45.5 \%, 15.3 \%$ and $29.6 \%$, respectively, compared to CSS. (Omara et al. 2011) investigated the

145 performance of solar still with fins and corrugate absorber plate. It was observed that the solar still with fins and

146 corrugated absorber plate had an improved freshwater yield by $40 \%$ and $21 \%$ respectively in relative to CSS.

147 (Jani and Modi 2019) studied the performance of solar still with circular and square hollow fins for better

148 productivity. Hollow fins are used to provide an enlarged surface area to absorb solar radiation as well as to

149 improve the heat transfer to the water. It was found that the solar still with circular fins obtained productivity of

$1501.4917 \mathrm{~kg} / \mathrm{m}^{2}$ per day whereas the solar still with hollow fins obtained productivity of $0.9672 \mathrm{~kg} / \mathrm{m}^{2} \mathrm{per}$ day.

151 (Kabeel et al. 2020) investigated the effect of hollow circular fins and phase change materials on the

152 productivity of pyramid solar still. It was noticed that the integration of hollow fins enhanced the productivity

153 by $43 \%$ whereas the productivity of solar still with both fins and energy storage improved the freshwater

154 productivity by $101.5 \%$ relative to the productivity of CSS.(Suraparaju et al. 2021; Suraparaju and Natarajan

155 2021a) studied the influence of absorber basin with bottom solid fins and hollow fins inserted in energy storage

156 (paraffin wax) on the freshwater yield of solar still. It was found that the solar still with solid finned absorber 
157 inserted in energy storage enhanced productivity by $24.26 \%$ compared to CSS. Whereas, the solar still with

158 hollow finned absorber basin inserted in energy storage showed an improvement in yield by $52.4 \%$ relative to

159 CSS. This phenomenon was mainly due to the more space in hollow fins for heat transfer between absorber and

160 energy storage compared to solid fins. (Suraparaju and Natarajan 2020) studied the influence of ridge gourd

161 natural fibre on the performance of solar still. It was found that the productivity was reduced by almost $3 \%$

162 when compared with the productivity of CSS. The reduction in productivity was mainly due to more fibres in

163 the absorber basin which hindered the incoming solar radiation to the absorber basin.

164 2.4. Increasing productivity by using nanomaterials

165 (Kabeel et al. 2019c) investigated the influence of $\mathrm{TiO}_{2}$ nano-coated absorber plate on the productivity of pyramid solar still at various water depths varying from $1 \mathrm{~cm}$ to $3.5 \mathrm{~cm}$. The $\mathrm{TiO}_{2}$ nanocoating is provided to

167 improve the absorptivity of solar radiation in the solar still. The experimental investigation of $\mathrm{TiO}_{2}$ nanocoated absorber resulted in improved productivity of $6.1 \%$ at $1 \mathrm{~cm}$ basin water depth relative to conventional solar still.

169 (Panchal et al. 2019) investigated the effect of $\mathrm{MgO}$ and $\mathrm{TiO}_{2}$ nanofluids with lower specific heat capacity and higher thermal conductivity in the solar still for better productivity. It was observed that the solar still with $\mathrm{MgO}$ nanofluids of $0.1 \%$ and $0.2 \%$ concentration had an increase in productivity by $33.33 \%$ and $45.8 \%$, respectively compared to CSS. Whereas the solar still with $\mathrm{TiO}_{2}$ nanofluids of $0.1 \%$ and $0.2 \%$ concentration had an increase in productivity by $4.1 \%$ and $20.4 \%$, respectively, compared to CSS. (Sharshir et al. 2019)assessed the performance of pyramid solar still with evacuated collectors and nanofluids. It was observed that the solar still with copper oxide and carbon black nanofluids enhanced the freshwater yield by $27.85 \%$ and $33.59 \%$.(Elango et al. 2015) studied the effect of different nanofluids on the productivity of solar still. It was reported that the solar still with $\mathrm{Al}_{2} \mathrm{O}_{3}, \mathrm{ZnO}$ and $\mathrm{SnO}_{2}$ had an increase in the potable water yield by $29.95 \%, 12.67 \%$ and $18.63 \%$, respectively, in relative to CSS.(Sharshir et al. 2018) investigated the influence of graphite and CuO nanofluids on the productivity of solar still. It was found that the solar still with graphite and $\mathrm{CuO}$ nanofluids had an augmented output of $41.18 \%$ and $32.35 \%$, respectively, compared to CSS.(Sathyamurthy et al. 2020) studied the influence of fumed silica nano-coating with different concentrations varying from $10 \%$ to $40 \%$ on the freshwater yield of solar still. It was observed that the solar still with a modified coating at $20 \%$ concentration had the

183 highest improvement in the yield by $34.2 \%$ compared to CSS. (El-gazar et al. 2021) investigated the influence of hybrid nanofluids (combination of $\mathrm{Al}_{2} \mathrm{O}_{3}-\mathrm{CuO}$ ) on the performance of solar still. It was observed that the solar still hybrid nanofluid enhanced the freshwater yield by $27.2 \%$ in summer and $21.7 \%$ in winter, respectively, when compared to CSS. 


\section{$187 \quad$ 2.5. Productivity enhancement by using energy storage materials}

188 (Attia et al. 2021a) studied the performance of phosphate bags as energy storage material in the solar still. It was

189 found that the cumulative productivity of solar still with energy storage at $1 \mathrm{~cm}$ and $2 \mathrm{~cm}$ water depth was about

$190 \quad 5.27$ and $4.87 \mathrm{~kg}$ whereas the CSS had a yield of $3.8 \mathrm{~kg}$. (Chamkha et al. 2020)analysed the performance of

191 solar still with Carbon Nano Tubes doped paraffin wax for enhancing the freshwater yield. It was found the 192 solar still with CNT doped paraffin wax improved the freshwater production by about $41.4 \%$ and $26.4 \%$ relative

193 to CSS and solar still with paraffin wax, respectively. (El et al. 2021). investigated the performance of El Oued 194 sand grains as energy storage in hemispherical solar still at a varying concentration from $0.5 \%$ to $7 \%$. It was 195 found that the hemispherical solar still with $3 \%$ El Oued sand grains had a better improvement in productivity 196 by $52.1 \%$ compared to CSS. (Balachandran et al. 2020) studied the effect of Gallus gallusdomesticus cascara as 197 energy storage material on the freshwater productivity of solar still. It was observed that the solar still with

198 Gallus gallusdomesticus cascara had a yield of $2.46 \mathrm{~L} / \mathrm{m}^{2}$ whereas the yield of CSS was about $2.07 \mathrm{~L} / \mathrm{m}^{2}$.

199 (Sathish Kumar et al. 2019) investigated the performance of finned absorber basin and energy storage on the 200 productivity of solar still. It was found that there was an increase in efficiency by $64 \%$ and $95 \%$ when only fins 201 and fins with energy storage are used respectively.

\section{$202 \quad$ 2.6. Productivity enhancement by increasing the condensation rate}

203 (Arunkumar et al. 2012) investigated the effect of glass cooling using water on the freshwater productivity of hemispherical solar still. It was observed that the decrease in the glass cover temperatures increased the energy efficiency from $34 \%$ to $42 \%$ with a fixed flow rate of $10 \mathrm{~mL} / \mathrm{min}$. (Pounraj et al. 2018) investigated the performance of Peltier based integrated PV/T solar still. It was observed that the Peltier system used in the system enhanced the distillate during both the evaporation and condensation process. The efficiency of Peltier based PV/T solar still was improved by 30\%. (Zanganeh et al. 2019, 2020) studied the performance of nanocoated condensing cover for improving the freshwater yield in solar still. It was found that the nano-coating over

210 the condensing surface improved productivity (20\% improvement for silicone coating) when compared to

211 uncoated surfaces. This phenomenon was mainly because the uncoated surface had less water dripping from the condensing surface. Also, the coated surfaces turn the film-wise condensation to dropwise condensation which

213 was a key factor for enhancing the productivity of solar still.(Elmaadawy et al. 2021) analysed the performance

214 of double slope solar still with the combination of low-cost materials and glass cover cooling for enhancing

215 freshwater productivity. It was found that the solar still with the combination of carbon black nanoparticles, 
216 gravel-covered with black wick and glass cover cooling had 68\% improvement in the freshwater productivity

217 compared to CSS.

\section{2.7. Combined improvement of evaporation and condensation rates for productivity enhancement}

219 (Rabhi et al. 2017) investigated the performance of solar still with pin fins absorber and external condenser for 220 better productivity. It was reported that the solar still with pin fins absorber and condenser had an improvement 221 in freshwater yield by $41.95 \%, 23.39 \%$ and $11 \%$ in relative to CSS, solar still with pin-fin absorber and solar 222 still with an external condenser, respectively.(Sathyamurthy et al. 2015) investigated the performance of solar 223 still with separate evaporation and condensation chambers. It was found that the solar still with PCM had an 224 improvement of $52 \%$ in the freshwater production compared to CSS. The separate condensation chamber enables the vapour to reject the heat to PCM due to higher temperatures of water vapour in the condensation chamber. Thus, the additional heat was absorber by PCM in the solar still and hence the productivity was improved. (Morad et al. 2015) studied the performance of solar still with flat plate collector and glass cooling arrangement for enhancing freshwater productivity. The results indicated that the active solar still had a productivity of $10.06 \mathrm{~L} / \mathrm{m}^{2}$ per day whereas the passive still attained only $7.8 \mathrm{~L} / \mathrm{m}^{2}$ per day.(Kumar et al. 2016)

230 analysed the performance of solar still with external condenser and agitating system for enhancing the potable water yield. In this research, the agitation effect by DC fan was accomplished to enhance the evaporation rate in

232 the basin and the condenser was integrated to enhance the condensation rate of solar still. The results of the 233 investigation reported that the modified solar still had an increase in yield by $39.49 \%$ compared to CSS.

\section{$234 \quad$ 2.8. Novelty of this study}

235 Based on the above literature, it can be outlined that many researchers worked on the improvement of 236 productivity of solar still by enhancing the evaporation or the condensation rate or by a hybrid approach. The evaporation rate of seawater in the absorber of the solar still was mainly enhanced by the usage of fins, energy

238 storage materials, wick materials, absorber coatings and surface enhancers like nanofluids and nanopowders. In addition to the evaporation, the condensation rate over the glass cover of the solar still was mainly enhanced by

240 several glass cooling techniques like equipping condensers, water dripping, nanofluids, glass coatings with

241 different materials etc. However, there were very few researches on the combined enhancement of evaporation 242 and condensation rates of solar still with various materials. It was also found that as of the authors' knowledge, 243 there were no words with a specific focus on naturally available, low-cost and environmentally friendly 244 materials to enhance the evaporation and condensation rate of solar still. In this regard, the current investigation focussed on enhancing the evaporation rate of seawater in the absorber basin by using powders like molasses 
246 powder, rice husk and sawdust. Also, the materials such as bamboo straw, banana leaf stem and rice straw were

247 utilized for enhancing the condensation rate over the glass cover of the solar still. Later, the best material which

248 enhanced the evaporation and the best material that enhanced the condensation rate was consideredfor further

249 investigation to analyse the combined influence of respective materials on the performance of single slope solar

250 still. In the end, the cost-effectiveness of all considered cases was estimated using economic analysis.

251 3. Experimentation and Materials

252 The experiments were carried out at the Solar Energy Laboratory, National Institute of Technology Puducherry,

253 Karaikal, India $\left(10.92^{\circ} \mathrm{N}, 79.83^{\circ} \mathrm{E}\right)$, during March and April 2021.

\section{3.1.An overview of selected low-cost and eco-friendly materials}

255 The low-cost and eco-friendly materials were used in the experiment for enhancing the evaporation as well as 256 condensation rate in the solar still. The materials chosen for this research was molasses powder, rice husk, sawdust, bamboo straw, banana leaf stem and rice straw. These materials were chosen because of their premium properties (Jagannadha Rao et al. 2008; Kalita et al. 2013; Bello RS and Onilude MA 2017) (mentioned in Table 1), low cost and their availability. The molasses powder, rice husk and sawdust enhance the evaporation rate due to improved wet surface area, which these powders had more absorptivity and more spread over the basin water. Besides, bamboo straw, banana leaf stem and rice straw enhance the condensation rate due to their porous structures(Ghaly et al.; Mounika et al. 2012; Sengphet et al. 2014; Sharma et al. 2015; Assis et al. 2015; Costes et al. 2017; Huang et al. 2017; Judawisastra et al. 2017),from which water can be continuously absorbed and reduce the glass cover temperatures throughout the experiment.

Table 1. Properties of the low cost and eco-friendly materials.

\begin{tabular}{|c|c|c|c|c|}
\hline \multicolumn{5}{|c|}{ Thermal } \\
\hline Material & $\begin{array}{l}\text { Conductivity } \\
\text { (W/m.K) }\end{array}$ & Density $\left(\mathrm{kg} / \mathrm{m}^{3}\right)$ & Porosity (\%) & Absorption (\%) \\
\hline Molasses Powder & 0.036 & 1200 & - & - \\
\hline Rice Husk & 0.0523 & 1030.93 & 63.64 & $5 \%$ to $16 \%$ \\
\hline Sawdust & 0.08 & 210 & $74 \%$ & - \\
\hline Bamboo Straw & 0.18 & 1163 & $43.9 \%$ & $26.2 \%$ \\
\hline Banana Leaf stem & 0.55 & 1370 & 18.5 & $9.7 \%$ \\
\hline Rice Straw & 0.05 & 450 & $71.21 \%$ & $234 \%$ \\
\hline
\end{tabular}


In this research, the experiments were conducted as three groups for augmenting the freshwater productivity in the single slope solar still. The three groups considered for experimentation are as follows:

a) Enhancing evaporation rate of seawater in the absorber basin

b) Enhancing condensation rate over the glass cover

c) Simultaneous enhancement of evaporation and condensation.

Besides this, eight various types of single slope solar stills were developed to carry out the three groups of experiments.

1. Conventional Solar Still (CSS)

a) Enhancing evaporation rate of seawater in the absorber basin

2. Solar Still with Molasses Powder (SSMP)

3. Solar Still with Rice Husk (SSRH)

4. Solar Still with Sawdust (SSSD)

b) Enhancing condensation rate over the glass cover

5. Solar Still with Bamboo straw (SSBS)

6. Solar Still with Banana Leaf Stem (SSBL)

7. Solar Still with Rice Straw (SSRS)

\section{c) Simultaneous enhancement of evaporation and condensation}

8. Solar Still with Sawdust and Rice Straw (SSSDRS)

\subsection{Materials and Fabrication of Single Slope Solar Still}

The single slope solar stills were made of strong and waterproof plywood and the inner structure of solar still was covered with an aluminium layer of $2 \mathrm{~mm}$ thicknessthatstops the direct contact between water vapour and plywood. The aluminium sheet was then coated with black paint for better absorption of incoming solar radiation. The absorber basin of each solar still was made of a $1 \mathrm{~mm}$ thick copper sheet. The dimensions of the absorber basin were $1000 \mathrm{~mm} \times 600 \mathrm{~mm} \times 50 \mathrm{~mm}$ (length $\times$ breadth $\times$ height) with an absorber area of $0.6 \mathrm{~m}^{2}$. Further, the solar still was covered with a $3 \mathrm{~mm}$ glass cover which was fixed at an angle of latitude of testing location $\left(11^{\circ}\right)$ for better working(Singh and Tiwari 2004). The absorber basins of all single slope solar stills were filled with seawater at a $2 \mathrm{~cm}$ basin water depth as it was found to be the optimum depth of water(Suraparaju and Natarajan 2021a). The outer structure of solar still was insulated with polystyrene sheets properties and was cost-effective. The absorber basins of SSMP, SSRH and SSSD were filled with molasses 
powder, rice husk and sawdust, respectively for enhancement of evaporation of seawater from the absorber

298 basin. The glass covers of SSBS, SSBL and SSRS have equipped with a water dripping arrangement consists of

299 a water tank, a dripping channel along with bamboo straw, banana leaf stem and rice straw, respectively, for

300 enhancing the glass cover condensation by reducing the glass temperatures. The schematic of the solar still with

301 glass cooling arrangement is as shown in Fig 1. The photograph of solar still arrangements of three sets of experiments is as shown in Fig 2a, 2b and 2c.

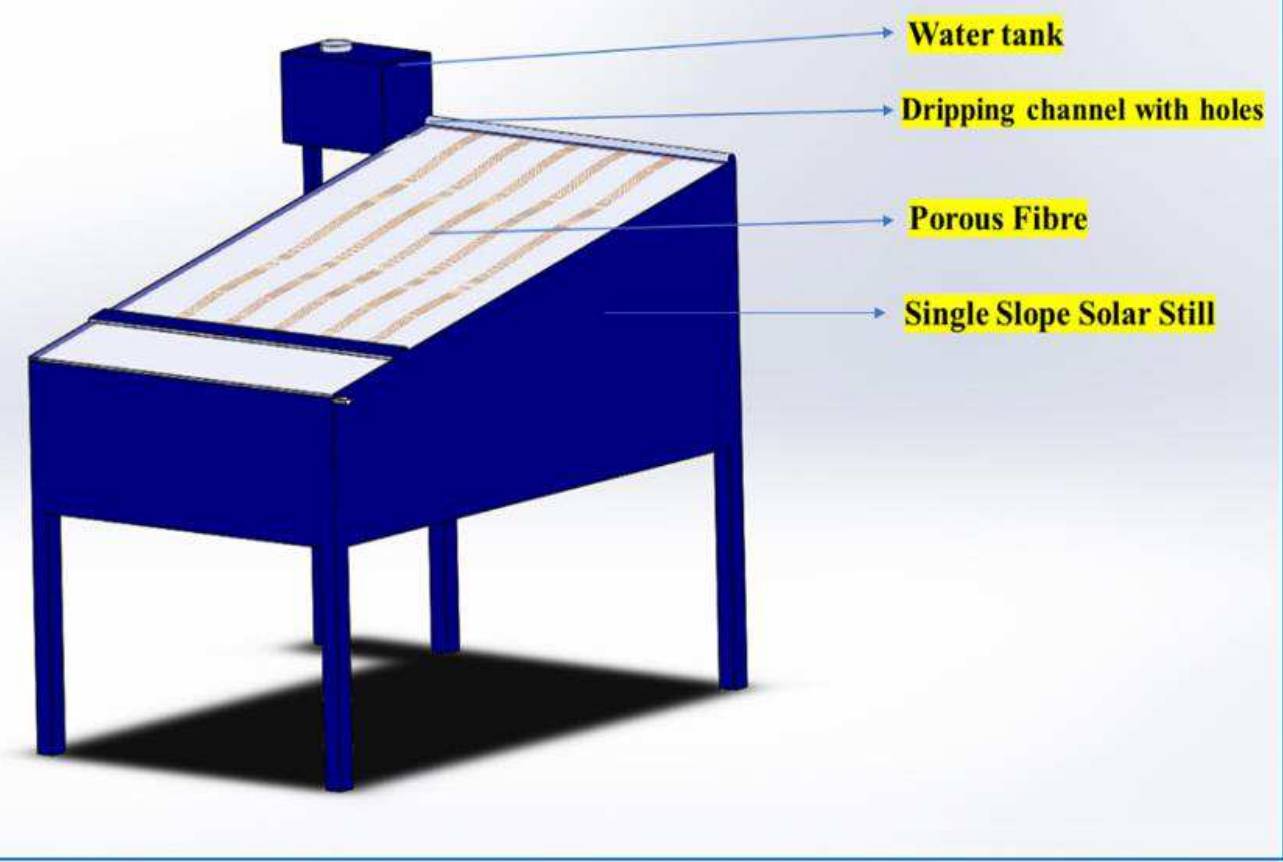

Fig. 1 Schematic of solar still with glass cooling arrangement. 

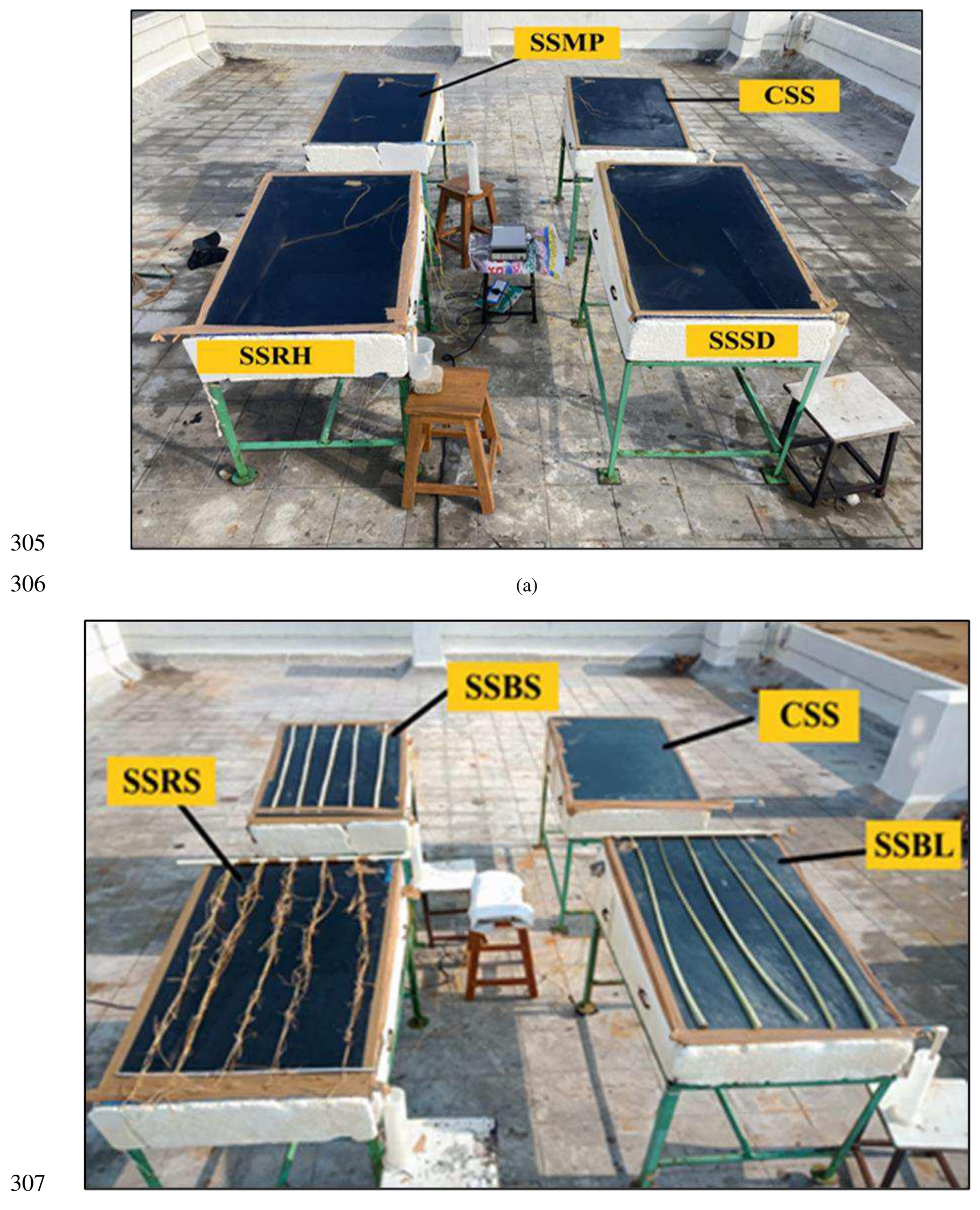


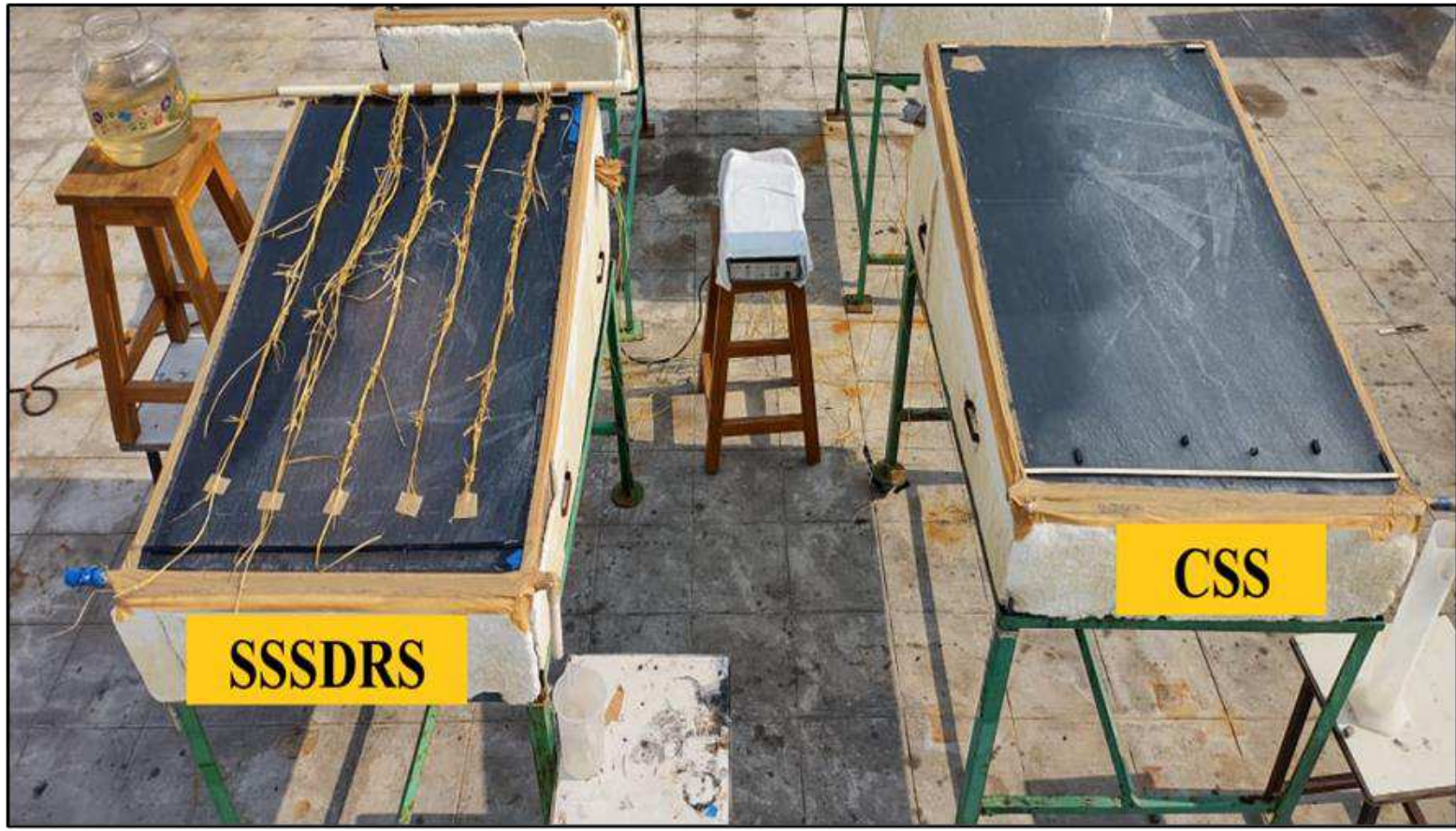

Fig. 2(a) Photograph of experimental arrangement for enhancing evaporation rate

(b) Photograph of experimental arrangement for enhancing condensation rate

(c) Photograph of experimental arrangement for simultaneous enhancement of evaporation and condensation rate.

\subsection{Experimentation and Error Analysis}

316 The experiments were carried out at the Solar Energy Laboratory, NIT Puducherry, Karaikal, India. The feed

317 water for the experiment was collected from the Bay of Bengal Sea located adjacent to the NIT Puducherry. The seawater in the absorber basin is filled to an optimum depth of $2 \mathrm{~cm}$ for better productivity(Suraparaju and Natarajan 2021a). The experiments on CSS, SSMP, SSRH and SSSD were conducted on $30^{\text {th }}$ March 2021 and $31^{\text {st }}$ March 2021 to investigate the effect of molasses powder (MP), rice husk (RH) and sawdust (SD) on the productivity of solar still by enhancing the evaporation rate of seawater in the absorber basin. The experiments on CSS, SSBS, SSBL, and SSRS were conducted on $1^{\text {st }}$ April 2021 and $2^{\text {nd }}$ April 2021 to investigate the effect of bamboo straw (BS), banana leaf stem (BL) and rice straw (RS) on the productivity of solar still by enhancing the condensation rate over the glass cover of the solar still. The experiments on the CSS and SSSDRS were conducted on $3^{\text {rd }}$ April 2021 and $4^{\text {th }}$ April 2021 to investigate the combined effect of sawdust and rice straw on the productivity of solar still by enhancing the evaporation rate and condensation rate simultaneously. The temperatures of the glass cover, seawater, absorber basin, glass cooling materials and ambient temperature were measured using K- type thermocouples connected to the "Data acquisition system". The global radiation of the 

conducted for six consecutive days, and readings were recorded from 08:30 am to 05:00 pm (Indian Standard formulae in Equations (1) - (3); (Bhargva and Yadav 2019; Taheri Mousavi et al. 2020; Suraparaju and Natarajan 2021b)

$$
u_{\eta}=\left[\left(\frac{\partial \eta_{d}}{d_{w}} \times u_{d_{w}}\right)^{2}+\left(\frac{\partial \eta_{d}}{I(t)} \times u_{I(t)}\right)^{2}\right]^{\frac{1}{2}}
$$

The uncertainty in hourly yield $\left(\mathrm{u}_{\mathrm{dw}}\right)$ is given by

$$
\begin{aligned}
& \mathrm{u}_{d_{w}}=\left[\left(\frac{\delta \mathrm{d}}{\delta \mathrm{y}_{1}} \mathrm{u}_{\mathrm{y}}\right)^{2}\right]^{\frac{1}{2}} \\
& \mathrm{u}_{d_{w}}=\left[\left(\frac{\mathrm{d}_{\mathrm{i}}-\mathrm{d}_{\mathrm{f}}}{\delta \mathrm{y}_{1}} u_{\mathrm{y}}\right)^{2}\right]^{\frac{1}{2}}
\end{aligned}
$$

Where $d_{i}$ and $d_{f}$ are the initial and final hourly yield in $\mathrm{mL}$ at any period and $\mathrm{u}_{\mathrm{y}}$ is the uncertainty of yield in percentage. It was evaluated that the uncertainty in hourly yield was $1 \%$ and further taking all other uncertainties into the account, the error in total yield was about $\pm 1.5 \%$. Besides that, the error in solar radiation and temperature measurement was $0.05 \%$ and $0.1 \%$. Thus, the total error percentage in the solar still efficiency was about $\pm 2 \%$.

\section{Thermal and Economic Analysis}

346 This section details the thermal and economic analysis performed for the experimented configurations of solar stills.

\section{$348 \quad$ 4.1. Thermal Analysis}

349 The overall thermal efficiency of the passive solar still is calculated by using Equation (4)(Kabeel and Abdelgaied 2016; Hassan and Abo-Elfadl 2017; Mande and Manickam 2019)

$$
\eta_{t h}=\frac{P \times \lambda}{A_{b} \times G}
$$

where $\mathrm{P}$ is the overall freshwater productivity in $\mathrm{kg}, \lambda$ is the latent heat of evaporation of water in $\mathrm{J} / \mathrm{kg}, \mathrm{A}_{\mathrm{b}}$ is the absorber basin area in $\mathrm{m}^{2}, \mathrm{G}$ is daily overall incident solar energy in $\mathrm{W} / \mathrm{m}^{2}$.

\section{4.2. Economic Analysis}

The key objective of the cost evaluation is to determine the cost per litre (CPL) per one $\mathrm{m}^{2}$ area of the solar still by using the Equations (5) - (14) (Omara and Kabeel 2014; Agboola et al. 2015; Tiwari and Sahota 2017) 
The first annual cost $(\mathrm{F})$ of the solar still is given by,

$$
F=C \times I
$$

359 Where $\mathrm{C}$ is the capital recovery factor and $\mathrm{I}$ is the initial investment,

$$
C=\frac{r(1+r)^{l}}{(1+r)^{l}-1}
$$

Where $r$ is the rate of interest and 1 is the lifespan of the solar still

362 The rate of interest was taken as $15 \%$ and the salvage value was taken as $20 \%$ of fixed cost.

$$
\text { The annual savage factor } A=S_{S} \times S
$$

364 Where $\mathrm{S}$ is the salvage value and $\mathrm{S}_{\text {sis }}$ the sinking fund factor

$$
\begin{aligned}
& S=0.2 \times I \\
& S_{S}=\frac{r}{(1+r)^{l}-1}
\end{aligned}
$$

The annual maintenance cost $\left(\mathrm{A}_{\mathrm{m}}\right)$ is anticipated to be $15 \%$ of the $\mathrm{F}$,

$$
A_{m}=0.15 \times F
$$

The annual cost $A_{c}=F+A_{m}-A$

$$
\text { Cost Per Liter } / m^{2}(C P L)=\frac{A_{c}}{Y_{l}}
$$

$$
\text { Payback Period }(P B P)=\frac{\text { Investment }}{\text { Total revenue per day }}
$$

Where $Y_{1}$ is the average yield per annum. It is given by the daily average freshwater productivity multiplied by the number of sunny and clear days (annually 300days) available for the working of solar still. The payback period of the particular solar desalination system is calculated by considering the initial investment, market price of one-litre water and total productivity per days given in equation $13 \& 14$.

378 The experiments were carried out during March and April 2021 with SSMP, SSRH, SSSD, SSBS, SSBL and

379 SSRS to investigate the performance of solar stills with various low-cost and eco-friendly materials. The SSMP,

380 SSRH and SSSD were investigated for enhancing the evaporation rate in the solar still. Whereas, the SSBS,

381 SSBL and SSRS were investigated for enhancing the condensation rate in the solar still. Later, the SSSDRS was

382 investigated for combined enhancement of evaporation and condensation rate in solar still for better 383 productivity. The observed results were compared with the results obtained from CSS.

\subsection{Global Solar Radiation}


385 The incident global solar radiation on all testing days from $30^{\text {th }}$ March 2021 to $04^{\text {th }}$ March 2021 was plotted against time (08:30 to 17:00 IST) as shown in Fig 3. The minimum, average and maximum incident global solar radiation on all testing days was plotted in Fig 4. From Fig 3\&4, it can be observed that the minimum, maximum and average solar radiation on all testing days were within the range of $210 \mathrm{~W} / \mathrm{m}^{2}$ to $250 \mathrm{~W} / \mathrm{m}^{2}, 1029$ $\mathrm{W} / \mathrm{m}^{2}$ to $1050 \mathrm{~W} / \mathrm{m}^{2}, 778 \mathrm{~W} / \mathrm{m}^{2}$ to $794 \mathrm{~W} / \mathrm{m}^{2}$, respectively.

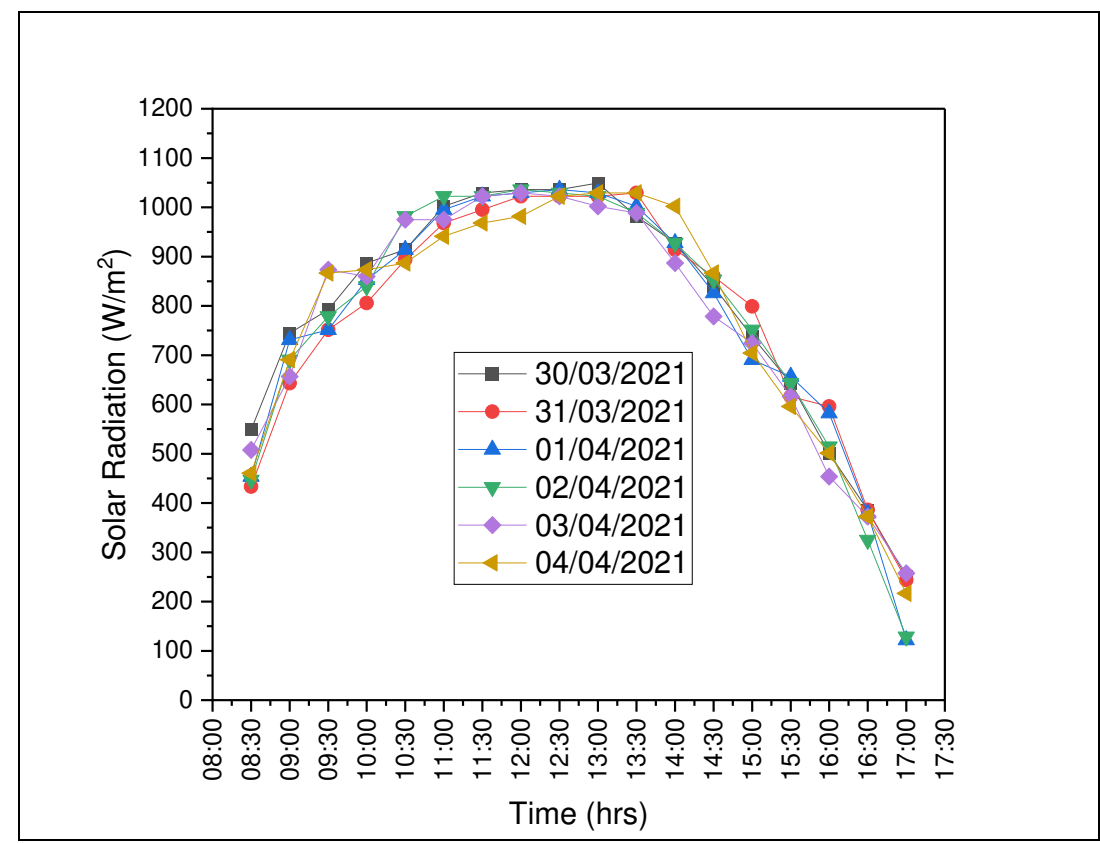

Fig.3. A plot of the variation of incident global solar radiation on all testing days for every 30 minutes.

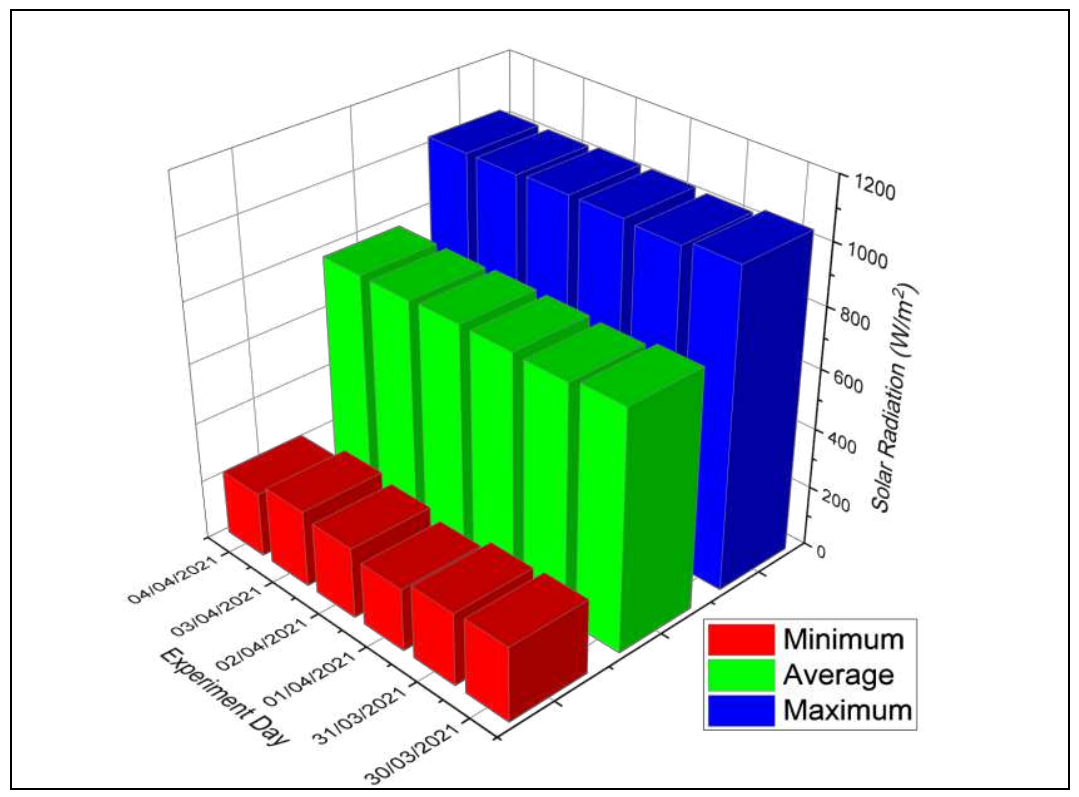

Fig.4. Maximum, minimum and average solar radiation on all testing days. 

the ambient temperature on all testing days was almost similar, ranging from $29^{\circ} \mathrm{C}$ to $43^{\circ} \mathrm{C}$. Also, the average ambient temperature on all six testing days was about $36^{\circ} \mathrm{C}$. The highest ambient temperatures were recorded during the peak hours from $11.30 \mathrm{hrs}$ to $14.30 \mathrm{hrs}$. The lowest ambient temperatures were recorded at the beginning and end of the experiment on all days.

400

401

402

403

404

405

406

407

408

409

410

411

412

413

414

415

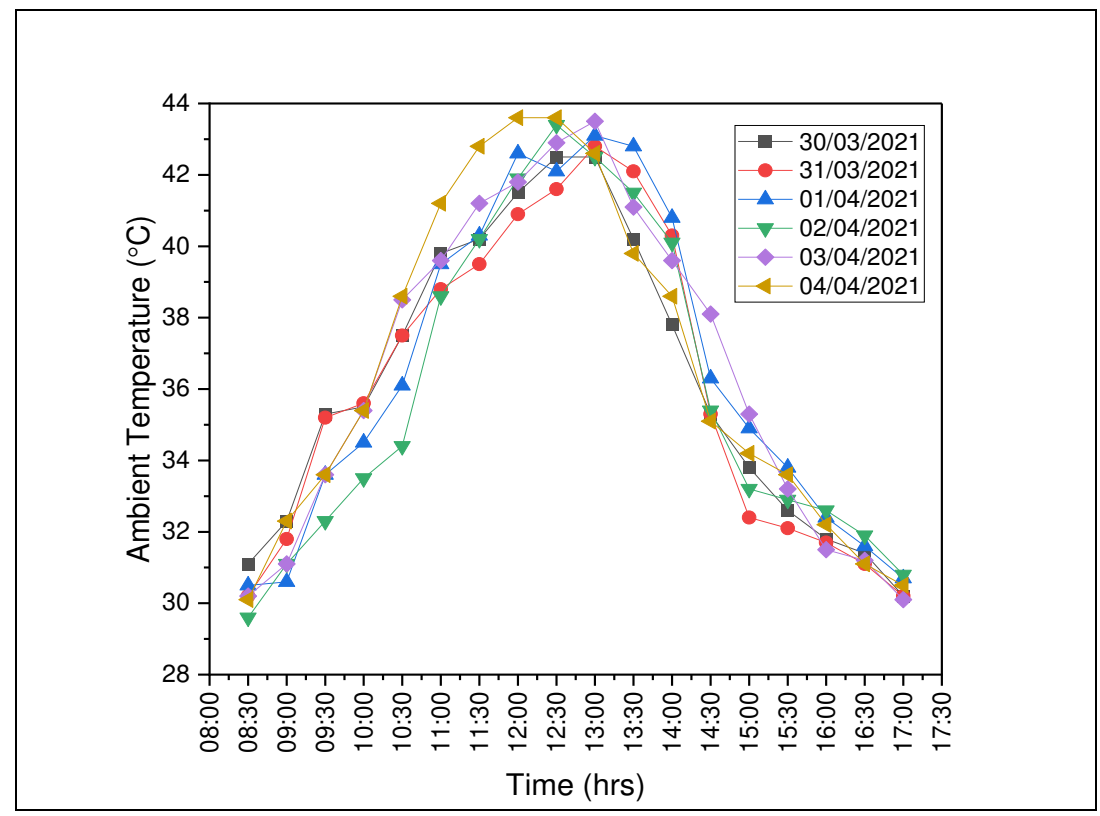

Fig.5.A plot of variation in ambient temperature on all testing days.

The variations of different temperatures in the CSS, SSMP, SSRH and SSSD on $30^{\text {th }}$ and $31^{\text {st }}$ March 2021were plotted against time as shown in Fig 6 and 7. The highest glass temperatures of the CSS, SSMP, SSRH and SSSD were recorded as $50.2^{\circ} \mathrm{C}, 57.8^{\circ} \mathrm{C}, 55.2^{\circ} \mathrm{C}$ and $57.2^{\circ} \mathrm{C}$, respectively, on $30^{\text {th }}$ March 2021 during the peak hours of experimentation. The maximum absorber temperatures of the CSS, SSMP, SSRH and SSSD were recorded as $69.7^{\circ} \mathrm{C}, 70.6^{\circ} \mathrm{C}, 70.5^{\circ} \mathrm{C}$ and $71.7^{\circ} \mathrm{C}$, respectively, on $30^{\text {th }}$ March 2021 during the peak hours of experimentation. The corresponding water temperatures of the CSS, SSMP, SSRH and SSSD were recorded as $68.2^{\circ} \mathrm{C}, 69.1^{\circ} \mathrm{C}, 68.9^{\circ} \mathrm{C}$ and $69.9^{\circ} \mathrm{C}$,respectively, on30 $0^{\text {th }}$ March 2021 . It was observed that the addition of molasses powder, rice husk and sawdust into the absorber basin enhanced the water temperatures compared to CSS. From Fig 7, it was noticed that the maximum glass temperatures of the CSS, SSMP, SSRH and SSSD were recorded as $51.3^{\circ} \mathrm{C}, 52.3^{\circ} \mathrm{C}, 52.3^{\circ} \mathrm{C}$ and $51.6^{\circ} \mathrm{C}$, respectively, on $31^{\text {st }}$ March 2021 during the peak hours of experimentation. The maximum absorber temperatures of the CSS, SSMP, SSRH and SSSD were recorded as $69.1^{\circ} \mathrm{C}, 70.1^{\circ} \mathrm{C}, 70.2^{\circ} \mathrm{C}$ and $71.1^{\circ} \mathrm{C}$, respectively, on $31^{\text {st }}$ March 2021 during the peak hours of experimentation. The corresponding water temperatures of the CSS, SSMP, SSRH and SSSD were recorded as $67.6^{\circ} \mathrm{C}, 69.1^{\circ} \mathrm{C}$, $69.2^{\circ} \mathrm{C}$ and $70.1^{\circ} \mathrm{C}$, correspondingly, on $31^{\text {st }}$ March 2021. It was observed that the addition of molasses powder, 
416 rice husk and sawdust into the absorber basin enhanced the water temperatures compared to CSS. Also, it was

417 reported that the addition of sawdust into the absorber basin raised the water temperature by almost $3 \%$ on both

418 days which tends to improve the evaporation rate from the absorber basin. The significant increase in the

419 temperature was mainly due to more absorption of heat by the sawdust compared to molasses powder and rice

420 husk. However, the molasses powder and rice husk improved the water temperatures comparatively better than

421 CSS due to their absorption from the incident solar radiation.

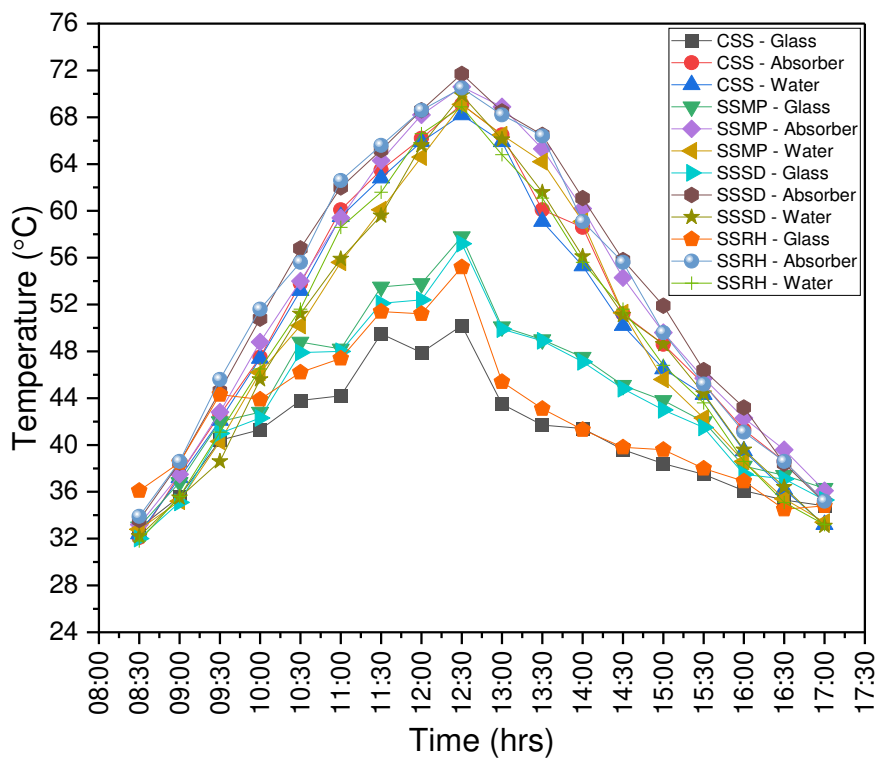

Fig.6.Solar Still temperatures on $30^{\text {th }}$ March 2021 (Enhancing evaporation rate). 


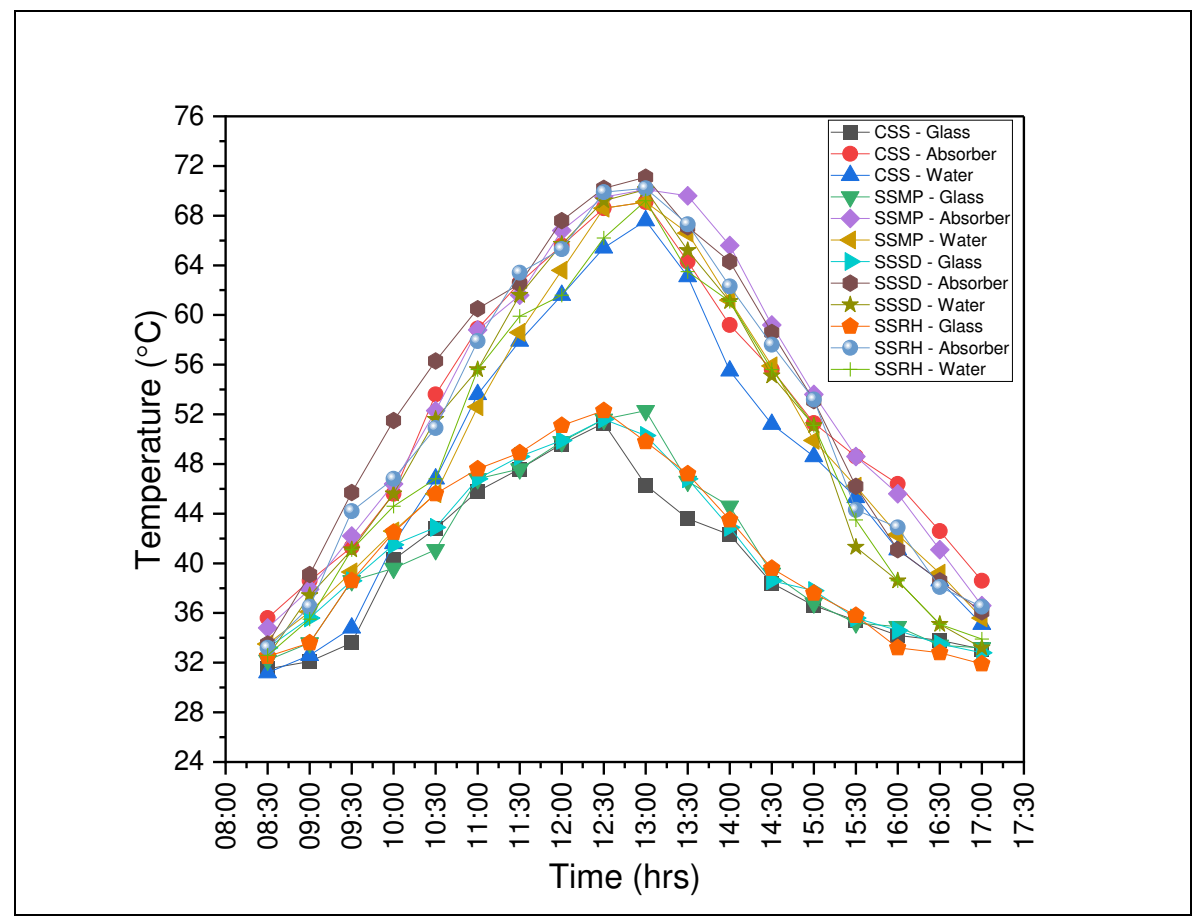

Fig.7. Solar Still temperatures on $31^{\text {st }}$ March 2021 (Enhancing evaporation rate).

426 The variations of different temperatures in the CSS, SSBS, SSBL and SSRSon $1^{\text {st }}$ and $2^{\text {nd }}$ April 2021 were plotted against time as shown in Fig 8 and 9. The highest glass temperatures of the CSS, SSBS, SSBL and SSRS were recorded as $49.2^{\circ} \mathrm{C}, 35.1^{\circ} \mathrm{C}, 35.8^{\circ} \mathrm{C}$ and $33.7^{\circ} \mathrm{C}$, respectively, on $1^{\text {st }}$ April 2021. The maximum fibre temperatures over the glass cover forSSBS, SSBL and SSRS were observed to be $34.6^{\circ} \mathrm{C}, 35.3^{\circ} \mathrm{C}$ and $33.2^{\circ} \mathrm{C}$, respectively. It was observed that the maximum temperatures of glass cover of SSBS, SSBL and SSRS were reduced due to glass cooling arrangement when compared to CSS without any glass cooling arrangement. Besides this, the maximum absorber temperatures of the CSS, SSBS, SSBL and SSRS were recorded at $67.7^{\circ} \mathrm{C}$, $69.2^{\circ} \mathrm{C}, 69.1{ }^{\circ} \mathrm{C}$ and $71.1^{\circ} \mathrm{C}$, respectively, on $1^{\text {st }}$ April 2021 during the peak hours of experimentation. The corresponding water temperatures of the CSS, SSBS, SSBLand SSRS were recorded as $66.8^{\circ} \mathrm{C}, 67.2^{\circ} \mathrm{C}, 68.8^{\circ} \mathrm{C}$ and $70.2^{\circ} \mathrm{C}$, respectively on $1^{\text {st }}$ April 2021. From Fig9, it can be observed that the maximum glass temperatures of the CSS, SSBS, SSBL and SSRS were recorded as $48.1{ }^{\circ} \mathrm{C}, 34.3^{\circ} \mathrm{C}, 36.5^{\circ} \mathrm{C}$ and $34.4^{\circ} \mathrm{C}$, respectively, on $2^{\text {nd }}$ April 2021 during the peak hours of experimentation. The maximum fibre temperatures over the glass cover for SSBS, SSBL and SSRS were observed as $33.8^{\circ} \mathrm{C}, 36.1^{\circ} \mathrm{C}$ and $33.2^{\circ} \mathrm{C}$, respectively. It was observed that the maximum temperatures of glass cover of SSBS, SSBL and SSRS were reduced due to glass cooling arrangement when compared to CSS without any glass cooling arrangement. In addition to this, the maximum absorber temperatures of the CSS, SSBS, SSBL and SSRS were recorded at $66.2^{\circ} \mathrm{C}, 67.7^{\circ} \mathrm{C}, 70.5^{\circ} \mathrm{C}$ and $72.5^{\circ} \mathrm{C}$, respectively, on the $2^{\text {nd }}$ April 2021during the peak hours of experimentation. The corresponding water temperatures of the CSS, SSBS, SSBL and SSRS were recorded as $65.4^{\circ} \mathrm{C}, 66.2^{\circ} \mathrm{C}, 70.2^{\circ} \mathrm{C}$ and 
$44471.7^{\circ} \mathrm{C}$,respectively, on $2^{\text {nd }}$ April 2021. The fibres absorbed the water after dripping and cool the glass till the 445 next drip which significantly reduced the glass temperatures continuously throughout the experiment. The 446 reduction of glass temperatures was mainly due to the porosity and water absorption capacity of the materials. It 447 was reported that the addition of glass cooling arrangement reduced the glass temperatures by $40 \%$ which 448 significantly increased the condensation rate over the glass and hence the productivity of solar still was 449 augmented.

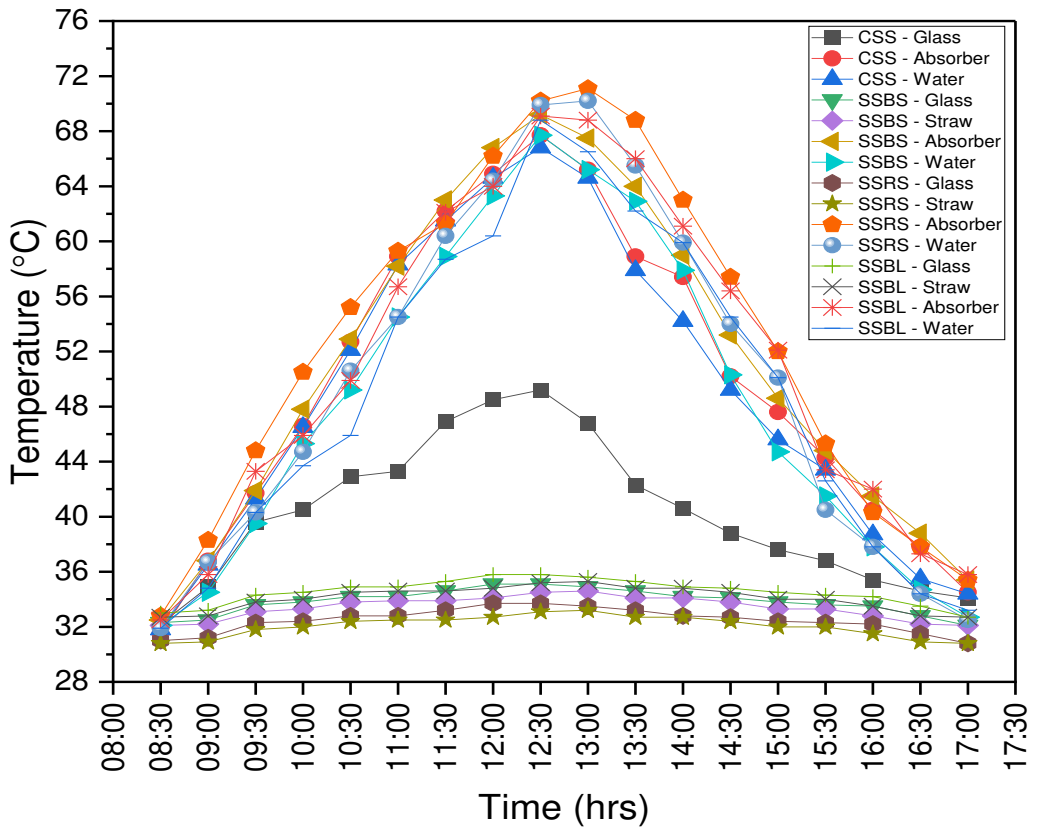

Fig.8. Solar Still temperatures on $1^{\text {st }}$ April 2021 (Enhancing condensation rate). 


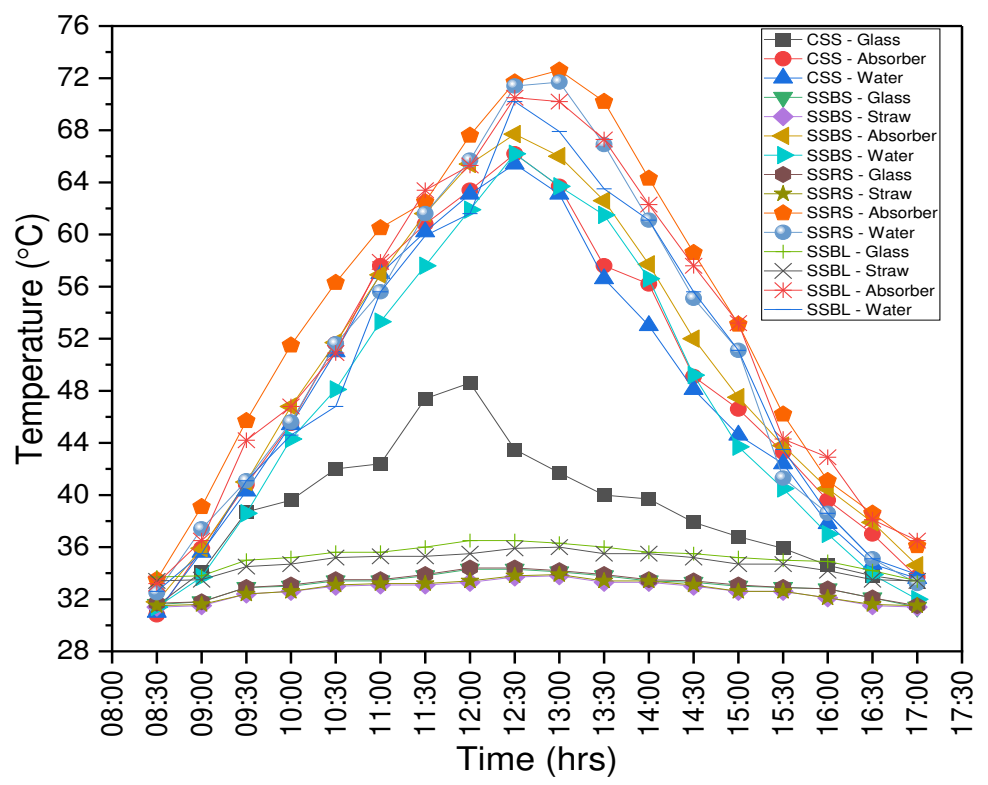

Fig.9.Solar Still temperatures on $2^{\text {nd }}$ April 2021 (Enhancing condensation rate).

454 The variations of different temperatures in the CSSand SSSDRS on $3^{\text {rd }}$ and $4^{\text {th }}$ April 2021 were plotted against

455 time as shown in Fig10 and 11. The highest glass temperatures of the CSS and SSSDRS were recorded as $45649.8^{\circ} \mathrm{C}$ and $32.9^{\circ} \mathrm{C}$, respectively, on $3^{\text {rd }}$ April 2021.The maximum fibre temperature over the glass cover for 457 SSSDRS was observed as $32.4^{\circ} \mathrm{C}$. The maximum absorber temperatures of the CSS and SSSDRS were recorded 458 at $68.6^{\circ} \mathrm{C}$ and $69.3^{\circ} \mathrm{C}$, respectively, on the $3^{\text {rd }}$ April 2021 during the peak hours of experimentation. The 459 corresponding water temperatures of the CSS and SSSDRS were recorded as $67.7^{\circ} \mathrm{C}$ and $68.4^{\circ} \mathrm{C}$, respectively, 460 on $3^{\text {rd }}$ April 2021. It was observed that the maximum temperatures of the glass cover of SSSDRS were reduced 461 due to the glass cooling arrangement when compared to CSS. From Fig11, the maximum glass temperatures of 462 the CSS, and SSSDRS were recorded as $50.6^{\circ} \mathrm{C}$ and $33.4^{\circ} \mathrm{C}$, respectively, on $4^{\text {th }}$ April 2021 . The maximum fibre 463 temperature over the glass cover for SSSDRS was observed to be $32.9^{\circ} \mathrm{C}$. The maximum absorber temperatures 464 of the CSS and SSSDRS were recorded as $69.7^{\circ} \mathrm{C}$ and $70.4^{\circ} \mathrm{C}$, respectively, on $4^{\text {th }}$ April 2021 during the peak 465 hours of experimentation. The corresponding water temperatures of the CSS and SSSDRS were recorded as $68.8^{\circ} \mathrm{C}$ and $69.5^{\circ} \mathrm{C}$, respectively, on $4^{\text {th }}$ April 2021. It was noticed that there was a significant rise in the water

467 temperatures and the maximum water temperature was maintained for a while which enhanced the evaporation 468 rate in the absorber basin. The thermophysical properties of SD supported to absorb more heat and thereby, 469 increasing the water temperature to aid in augmenting the evaporating rate. Similarly, the porosity and the 470 water-retaining ability of RS produced a natural cooling effect on the glass by maintaining the glass temperature 

surface which directly reflected in higher yield or productivity.

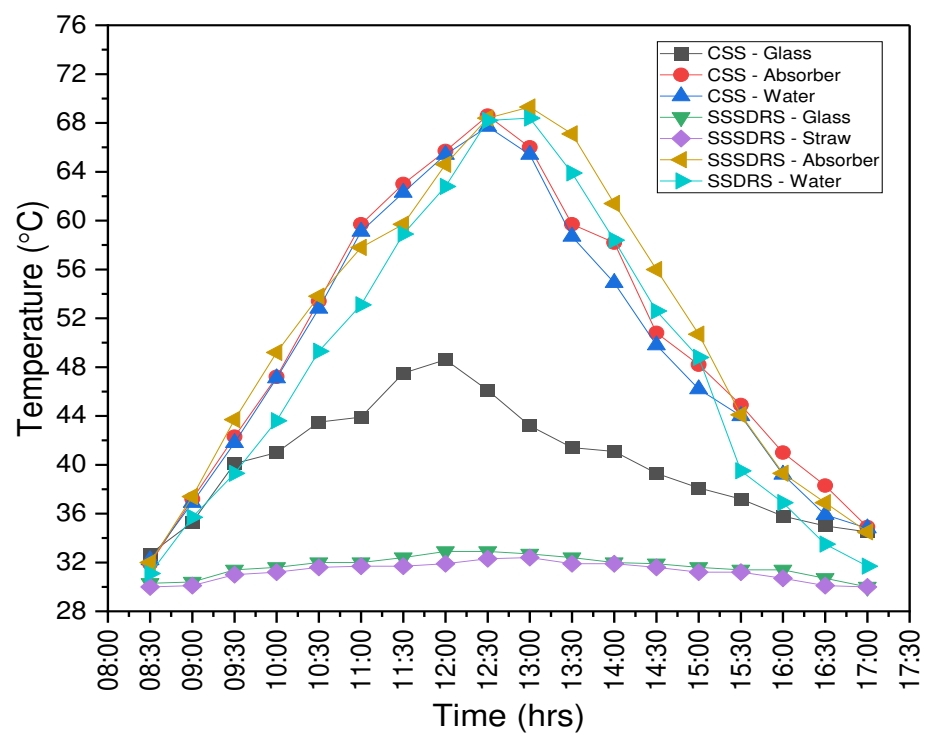

Fig. 10.Solar Still temperatures on $3^{\text {rd }}$ April 2021 (Enhancing evaporation \& condensation rate).

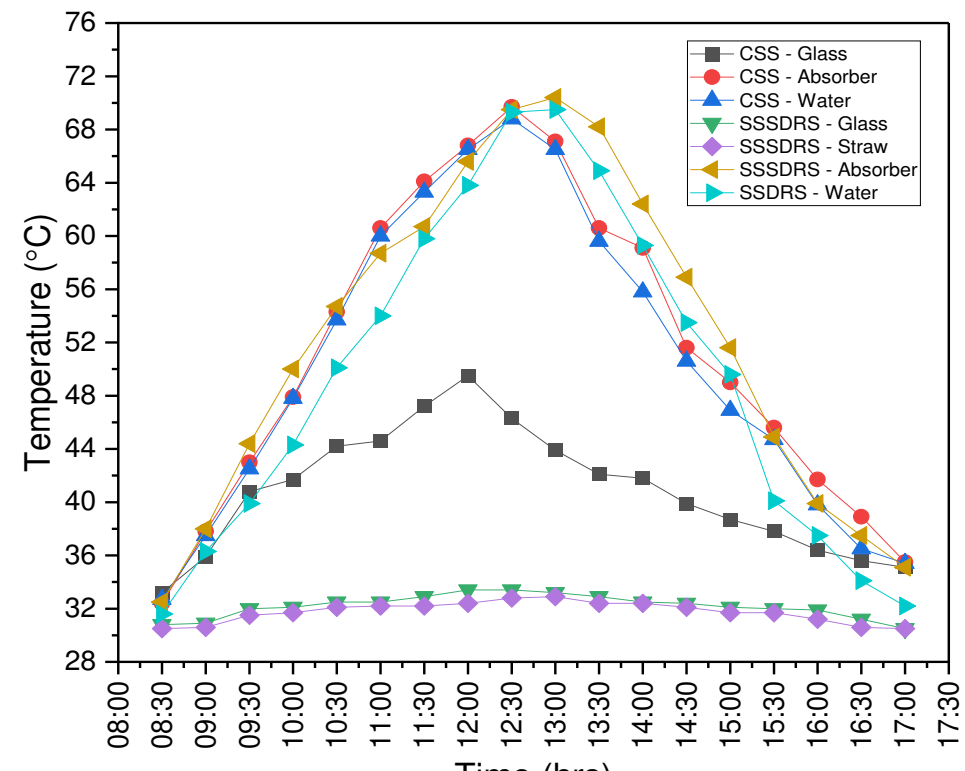

Time (hrs)

Fig. 11. Solar Still temperatures on $4^{\text {th }}$ April 2021 (Enhancing evaporation \& condensation rate). 


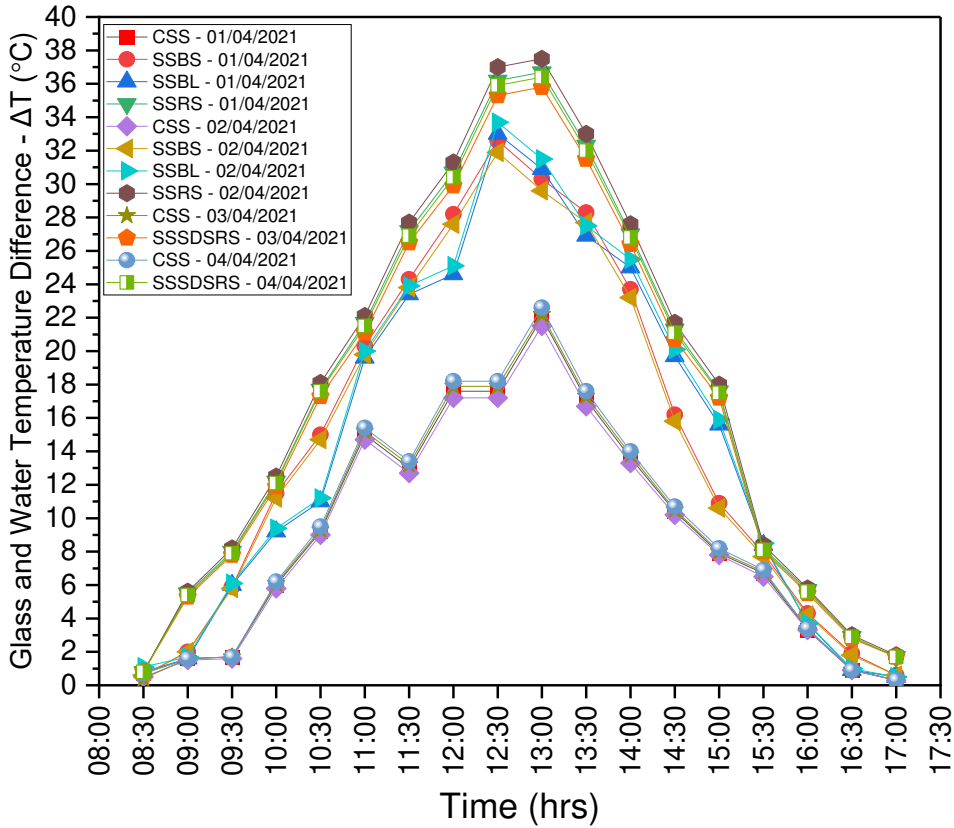

Fig. 12.Difference between glass cover and basin water temperatures.

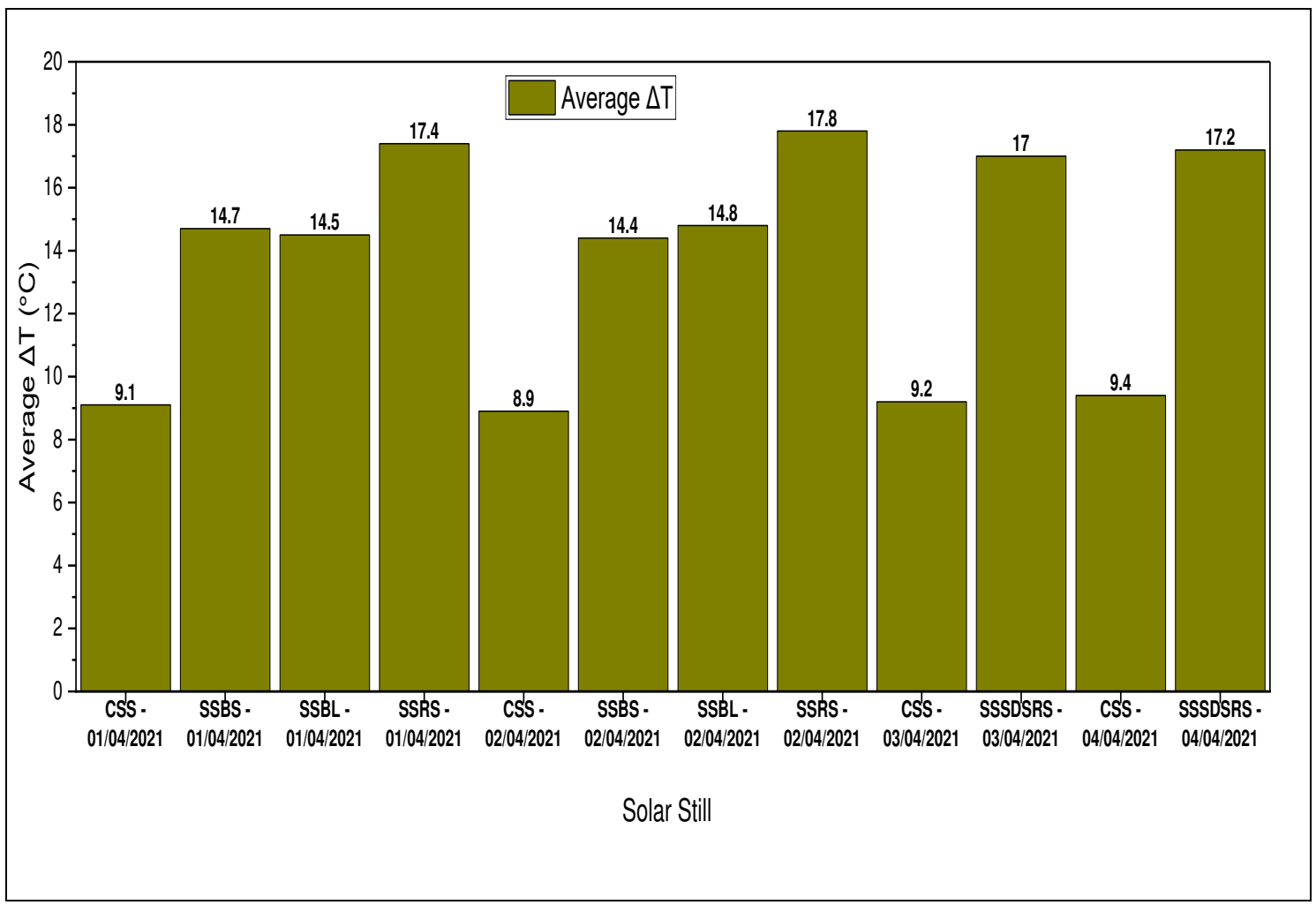

Fig. 13.The average difference between glass cover and basin water temperatures.

481 The variations in the water and glass temperature difference $\left(\Delta T=T_{\text {water }}-T_{\text {glass }}\right)$ which was the key factor

482 for enhancing the productivity was plotted against time as shown in Fig 12 . The $\Delta \mathrm{T}$ was plotted for the

483 experiment days $01^{\text {st }}$ April to $04^{\text {th }}$ April 2021 where the novel glass cooling arrangement was equipped with 

and SSSDRS was attained as $22^{\circ} \mathrm{C}, 32^{\circ} \mathrm{C}, 33^{\circ} \mathrm{C}, 36^{\circ} \mathrm{C}$ and $36^{\circ} \mathrm{C}$, respectively. It was noticed that the maximum

$486 \Delta \mathrm{T}$ of CSS and SSSDRS had a greater difference of $14^{\circ} \mathrm{C}$ which played a significant role in reducing the glass cover temperatures and increasing the condensation rate over the glass cover. Also, the average $\Delta \mathrm{T}$ of all the considered cases were plotted as a bar diagram in Fig 13. It was observed that the average $\Delta \mathrm{T}$ values of CSS, SSBS, SSBL, SSRS and SSSDRS were almost $9^{\circ} \mathrm{C}, 15^{\circ} \mathrm{C}, 15^{\circ} \mathrm{C}, 17^{\circ} \mathrm{C}$ and $17^{\circ} \mathrm{C}$, respectively. The significant average $\Delta \mathrm{T}$ values increased the condensation rate and hence the productivity of SSBS, SSBL, SSRS and SSSDRS was improved when compared to CSS.

\section{5.3. Freshwater Yield}

493 The cumulative yield of CSS, SSMP, SSRH and SSSD on $30^{\text {th }}$ and $31^{\text {st }}$ March 2021 were plotted as Fig 14. 494 Besides, the cumulative yield of CSS, SSBS, SSBL and SSRS on $1^{\text {st }}$ and $2^{\text {nd }}$ April 2021 were plotted as Fig 15. 495 The cumulative yield of CSS and SSSDRS on $3^{\text {rd }}$ and $4^{\text {th }}$ April 2021 were plotted as Fig 16. It was observed from 496 Fig14 that the cumulative productivity of SSSD was higher when compared to SSMP, SSRH and CSS. The cumulative yield of SSSD was about $2983 \mathrm{~mL} / \mathrm{m}^{2}$ and $3033 \mathrm{~mL} / \mathrm{m}^{2}$ on $30^{\text {th }}$ and $31^{\text {st }}$ March 2021,respectively. On $1^{\text {st }}$ and $2^{\text {nd }}$ April 2021, it was observed that the cumulative productivity of SSRS was higher when compared to SSBS, SSBL and CSS. The cumulative productivity of SSSD was about $3367 \mathrm{~mL} / \mathrm{m}^{2}$ and 3350 $\mathrm{mL} / \mathrm{m}^{2}$,respectively. From Fig 16, it can be observed that the cumulative productivity of SSSDRS was higher when compared to CSS. The cumulative productivity of SSSDRS was about $3583 \mathrm{~mL} / \mathrm{m}^{2}$ and $3633 \mathrm{~mL} / \mathrm{m}^{2}$ on $3^{\text {rd }}$ and $4^{\text {th }}$ April 2021, respectively. The maximumproductivities of all considered cases were plotted as a bar diagram in Fig17. From Fig17, it was observed that the maximum productivities of CSS on all testing days were about $2200 \mathrm{~mL} / \mathrm{m}^{2}$. The cumulative productivities of SSMP were about $2350 \mathrm{~mL} / \mathrm{m}^{2}$ whereas the cumulative productivities of SSRH were about $2450 \mathrm{~mL} / \mathrm{m}^{2}$. The cumulative productivities of SSBS and SSBL were about $2700 \mathrm{~mL} / \mathrm{m}^{2}$.

507 From the above inferences, it was clear that the sawdust in the absorber basin of solar still improved the evaporation rate comparatively better than rice husk and molasses powder. The main reason for this phenomenon was the better physio-thermal properties of sawdust compared to other materials. The density of

510 sawdust was comparatively less than the molasses powder and rice husk. The less-dense sawdust float over the 511 water in the absorber basin which enhanced the surface area of evaporation. Also, the thermal conductivity of 512 sawdust was comparatively higher than the other two materials which enhanced the water temperatures in the 513 absorber basin of solar still. The molasses powder and rice husk also showed an increment in freshwater yield 
514 compared to CSS due to their individual physio-thermal properties. On the other hand, the condensation rate of

515 solar still was improved better by rice straw than bamboo straw and banana leaf stem. The main reason for this

516 occurrence was the better porosity and water absorption capacity of rice straw. The porosity of rice straw was

517 almost $80 \%$ which was higher relative to banana leaf stem and bamboo straw. Also, the water absorption

518 capacity of rice straw was significantly higher than that of the other two materials. Hence, the rice straw with

519 better porosity and water absorption capacity had great contact with water from the dripping arrangement which

520 subsequently reduced the glass cover temperatures of solar still. The reduced glass cover temperatures lead to

521 improved freshwater yield from the solar still with rice straw. Nevertheless, the bamboo straw and banana leaf

522 stem also improved the freshwater productivity relatively higher than CSS according to their inherent properties.

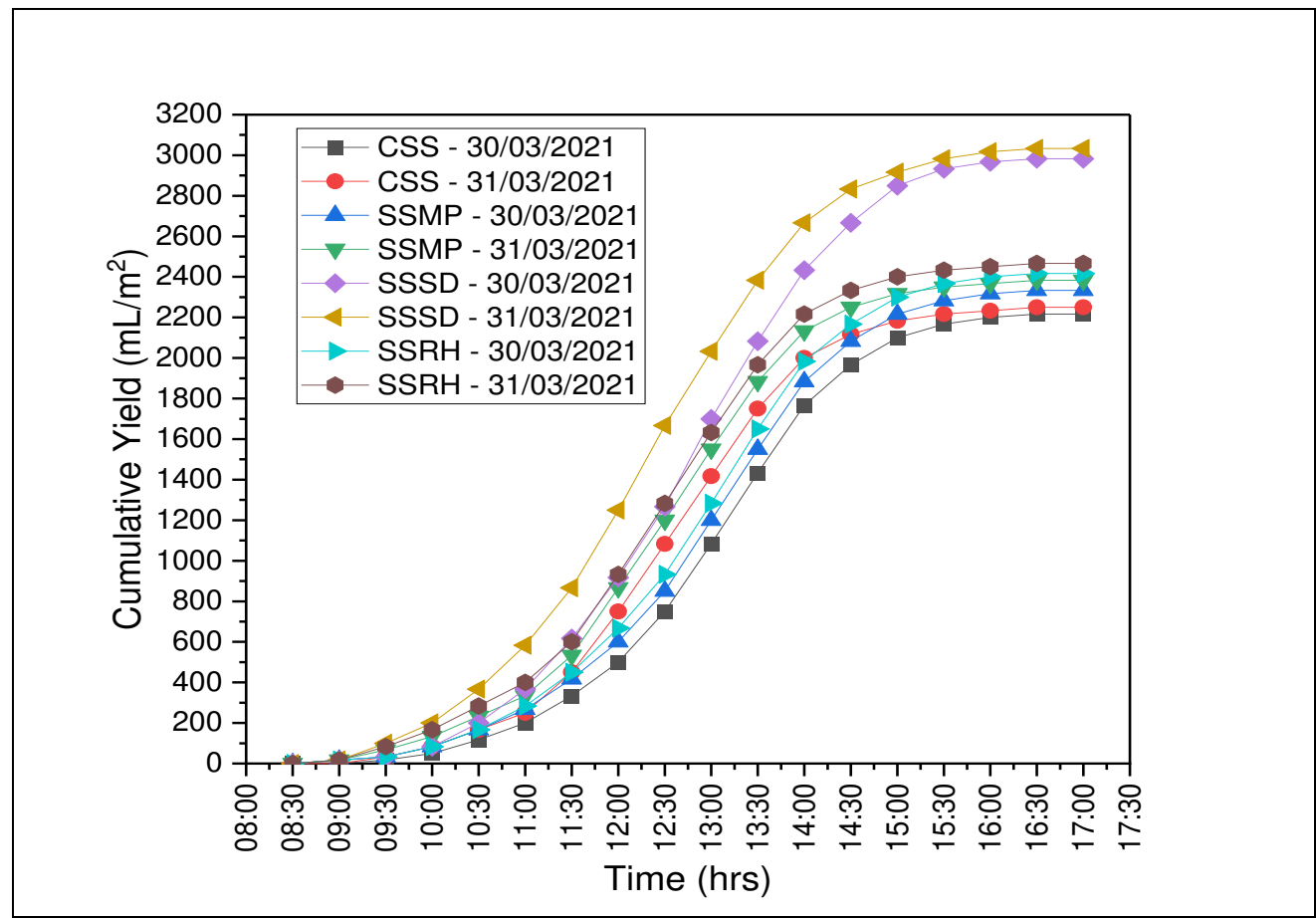

Fig. 14.The cumulative yield of solar stills during $30^{\text {th }}$ and $31^{\text {st }}$ March 2021 (Enhancing evaporation rate). 


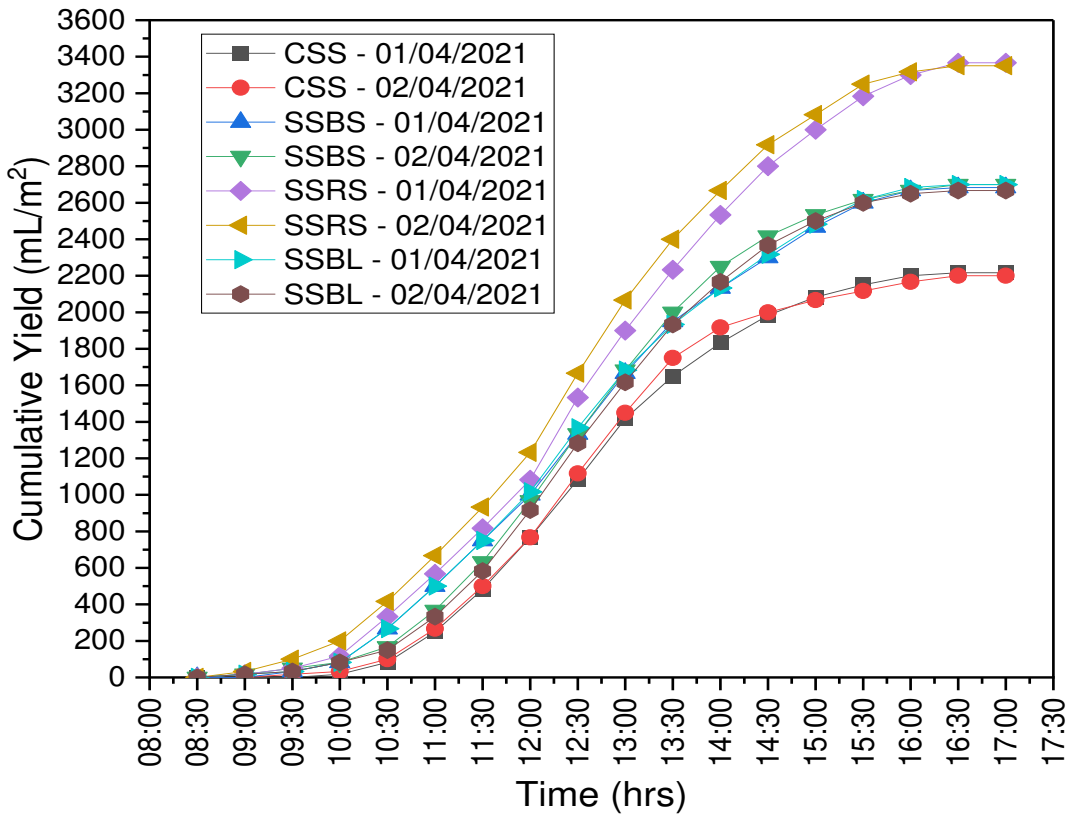

526 Fig. 15.The cumulative yield of solar stills during $1^{\text {st }}$ and $2^{\text {nd }}$ April 2021 (Enhancing condensation rate).

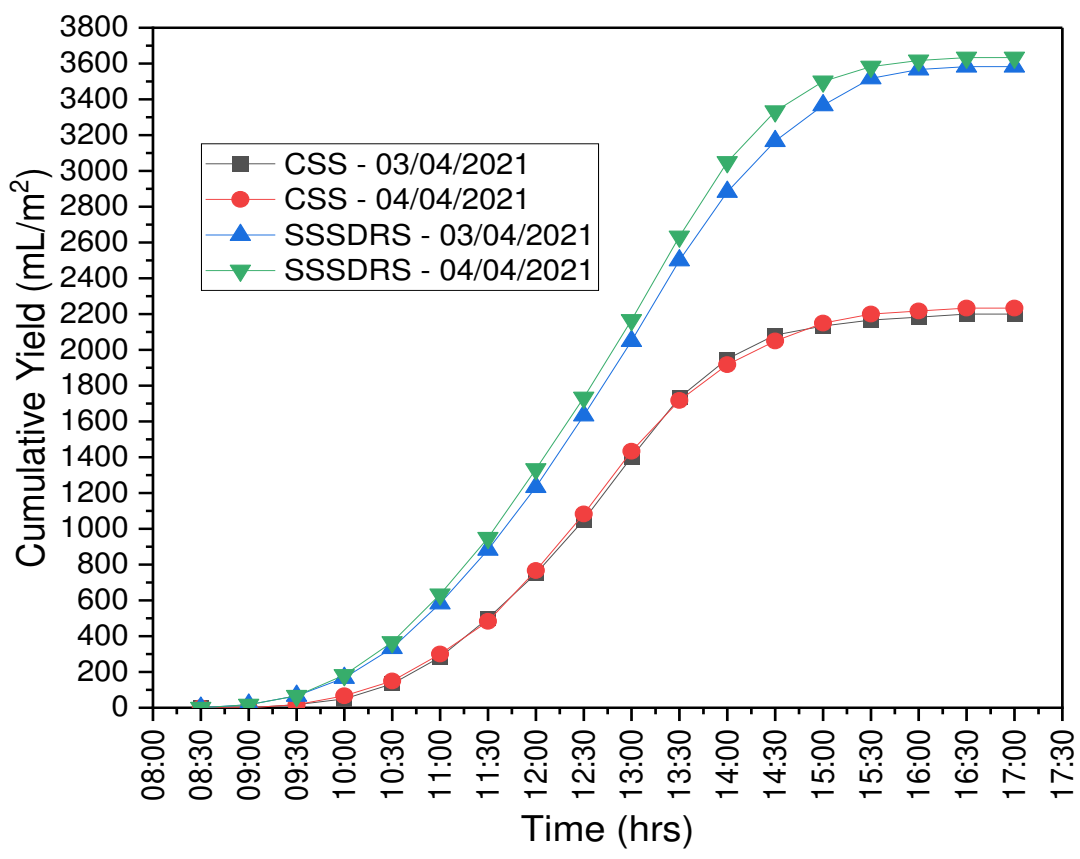

Fig. 16.The cumulative yield of solar stills during $3^{\text {rd }}$ and $4^{\text {th }}$ April 2021 (Enhancing evaporation \& condensation rate). 


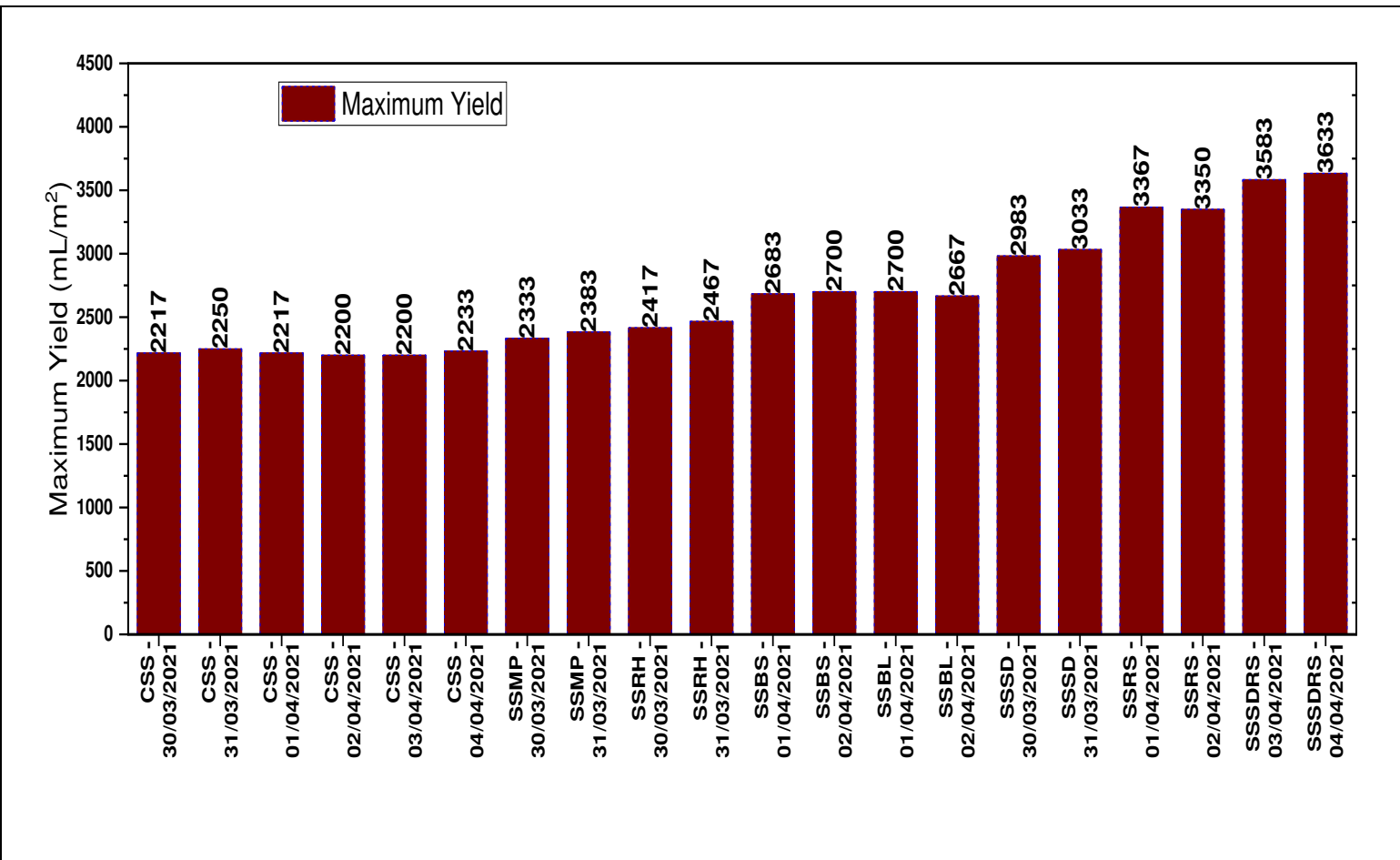

Fig. 17.Comparison of maximum yield of all solar stills throughout the experimentation period.

532 The increase in the productivities of SSMP, SSRH, SSSD, SSBS, SSBL, SSRS, and SSSDRS compared to CSS

533 were plotted as a bar diagram in Fig18. It was clear that the increase in the maximum yield of SSSD and

534 SSRSwas about 34\% and 52\%, respectively, when compared to CSS. The SSSD and SSRS were the highest

535 among the evaporation group and condensation group experiments. The combination of SSDS and SSRS,

536 termed as SSSDRS, was experimentally studied for enhancing the evaporation and condensation simultaneously.

537 It was observed that the increase in the maximum yield of SSSDRS was about $62 \%$ when compared to CSS.

538 Also, the increase in the productivities of SSMP, SSRH, SSBS and SSBL was about $6 \%, 9 \%, 21 \%$ and $22 \%$,

539 respectively, when compared to CSS. 


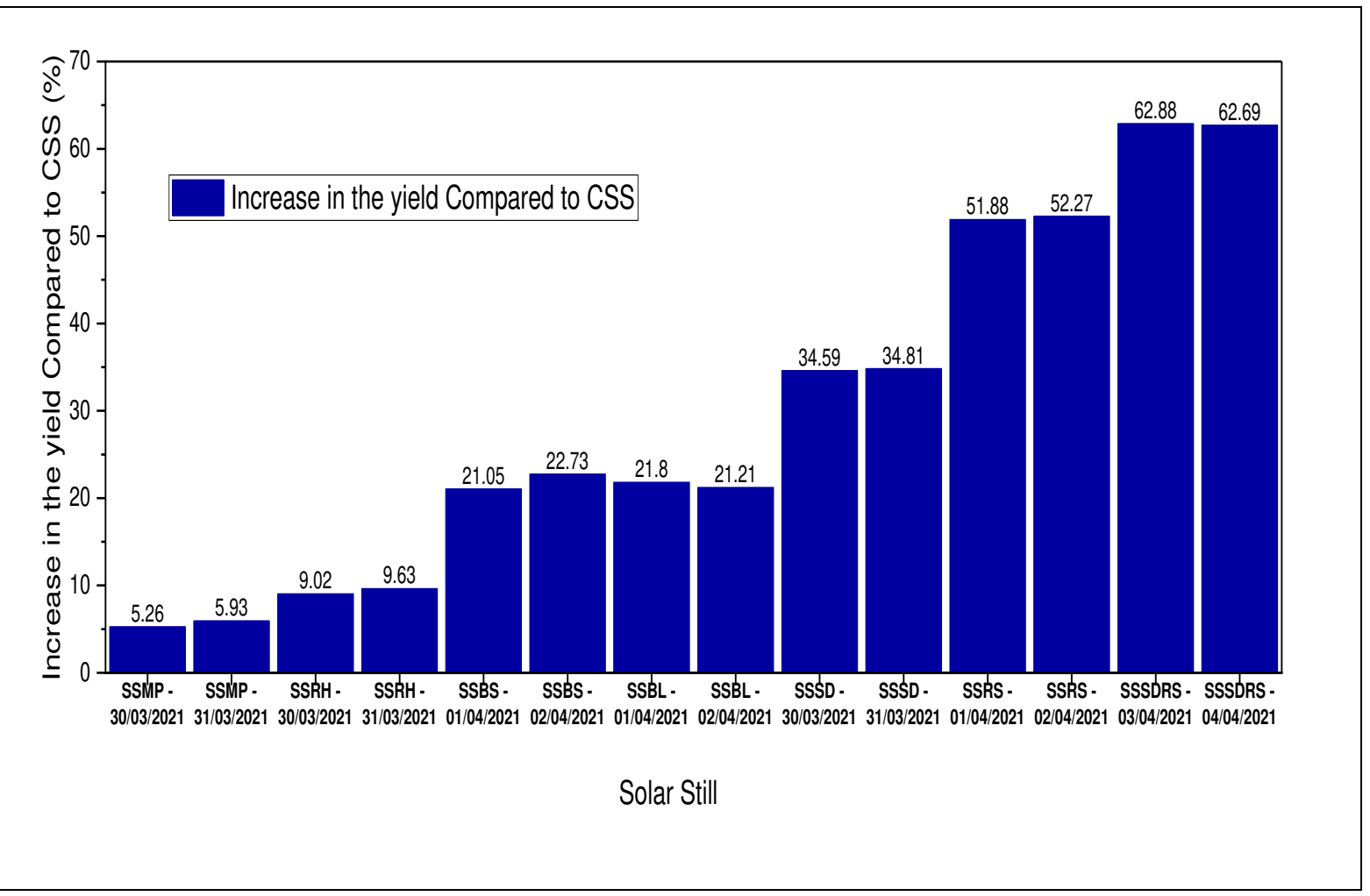

Fig. 18. Increase in the yield \% of modified solar stills compared to CSS.

542 5.4. Effect of low cost and eco-friendly materials on the system temperatures and productivity of solar

543 stills

544 The inclusion of low cost and eco-friendly materials into the solar still improved the temperatures of the system.

545 The molasses powder, rice husk and sawdust improved the evaporation rate in the absorber basin by absorbing

546 more solar radiation through increasing the surface area in the absorber basin. The molasses powder, rice husk

547 and sawdust augmented the water temperature by $3 \%$ when compared to CSS. Also, these materials helped to

548 maintain the maximum water temperature for a while which enhanced the evaporation rate in the absorber basin

549 when compared to CSS. The main reason behind the increased water temperatures was the more heat absorption

550 from the materials used in the absorber basin. The surge in the water temperatures leads to an augmentation of

551 freshwater yield in SSMP, SSRH and SSSD, respectively, when compared to CSS. Besides, the integration of

552 bamboo straw, banana leaf stem and rice straw to the water dripping arrangement for glass cooling enhanced the

553 condensation rate through their porous structures. The porous structures and water-absorbing capacity of

554 materialscontinuously absorbed the water from the dripping arrangement and helped in reducing the glass cover

555 temperatures throughout the experiment. The inclusion of bamboo straw, banana leaf stem and rice straw

556 reduced the glass cover temperature by above $40 \%$ relative to CSS. The decrement in the glass cover

557 temperatures enhanced the condensation rate over the glass cover when compared to CSS. The surge in the 
to CSS. Nevertheless, the inclusion of low cost and eco-friendly materials into the solar still augmented the

560 water temperatures and reduced the glass cover temperatures that led to an improvement in the freshwater yield

561 of solar still.

\section{5.5. Thermo - Economic Analysis}

563 The overall thermal efficiency of the single-slope solar stills was assessed using equation (4). The thermal

564 efficiency of all the considered cases was plotted as a bar diagram in Fig 19. From Fig 19, it was observed that the thermal efficiency of CSS on all days was about $36 \%$. The thermal efficiencies of SSMP, SSRH and SSSD were about $37 \%, 39 \%$ and $48 \%$, respectively. Whereas, the thermal efficiencies of SSBS, SSBL and SSRS were about $43 \%, 43 \%$ and $54 \%$, respectively. The thermal efficiency of SSSDRS was reported as 59\% which was the highest among all the other cases. From the above observations, it can be concluded that the inclusion of lowcost and eco-friendly materials into the system improved the performance of single slope solar still by increasing the system temperatures, productivity and energy efficiency.

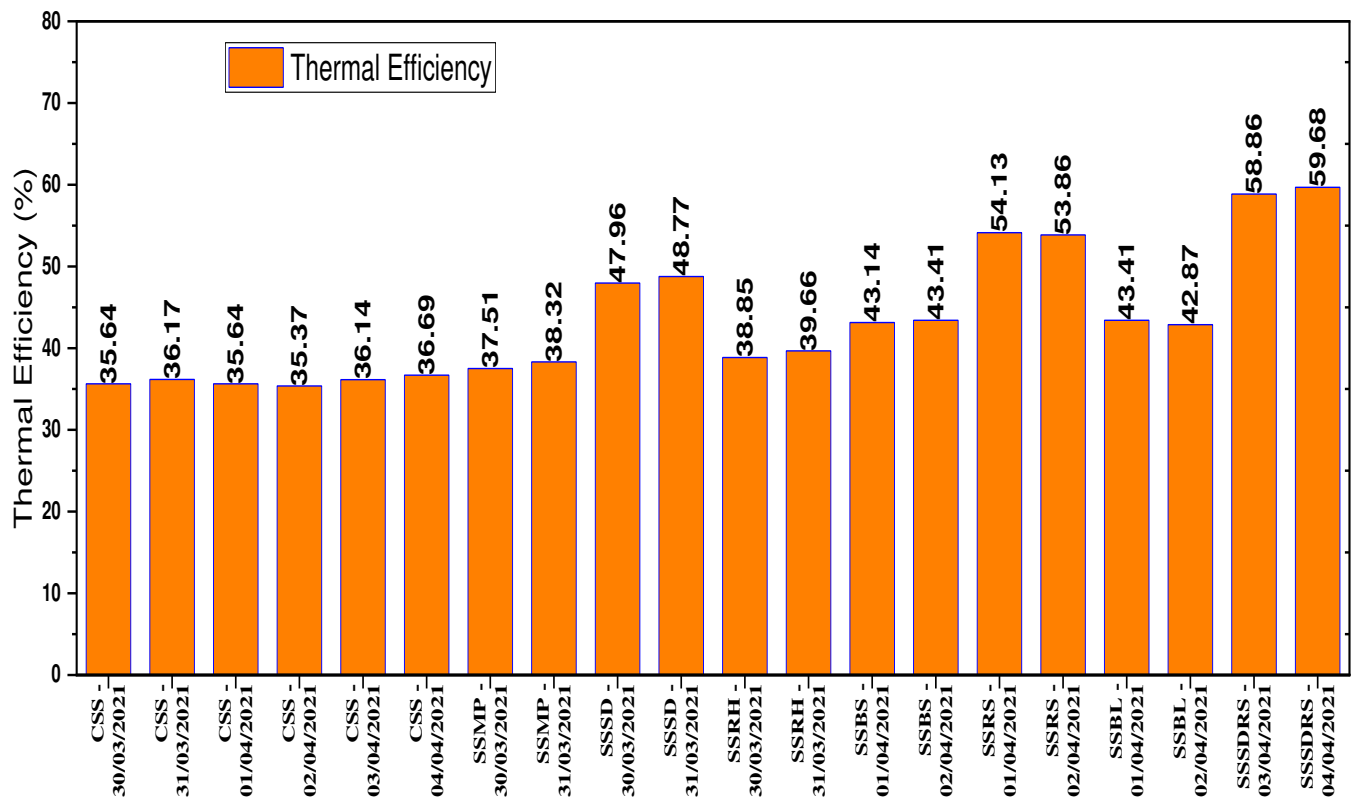

Solar Still

Fig.19.Comparison of thermal efficiencies of all solar stills. 


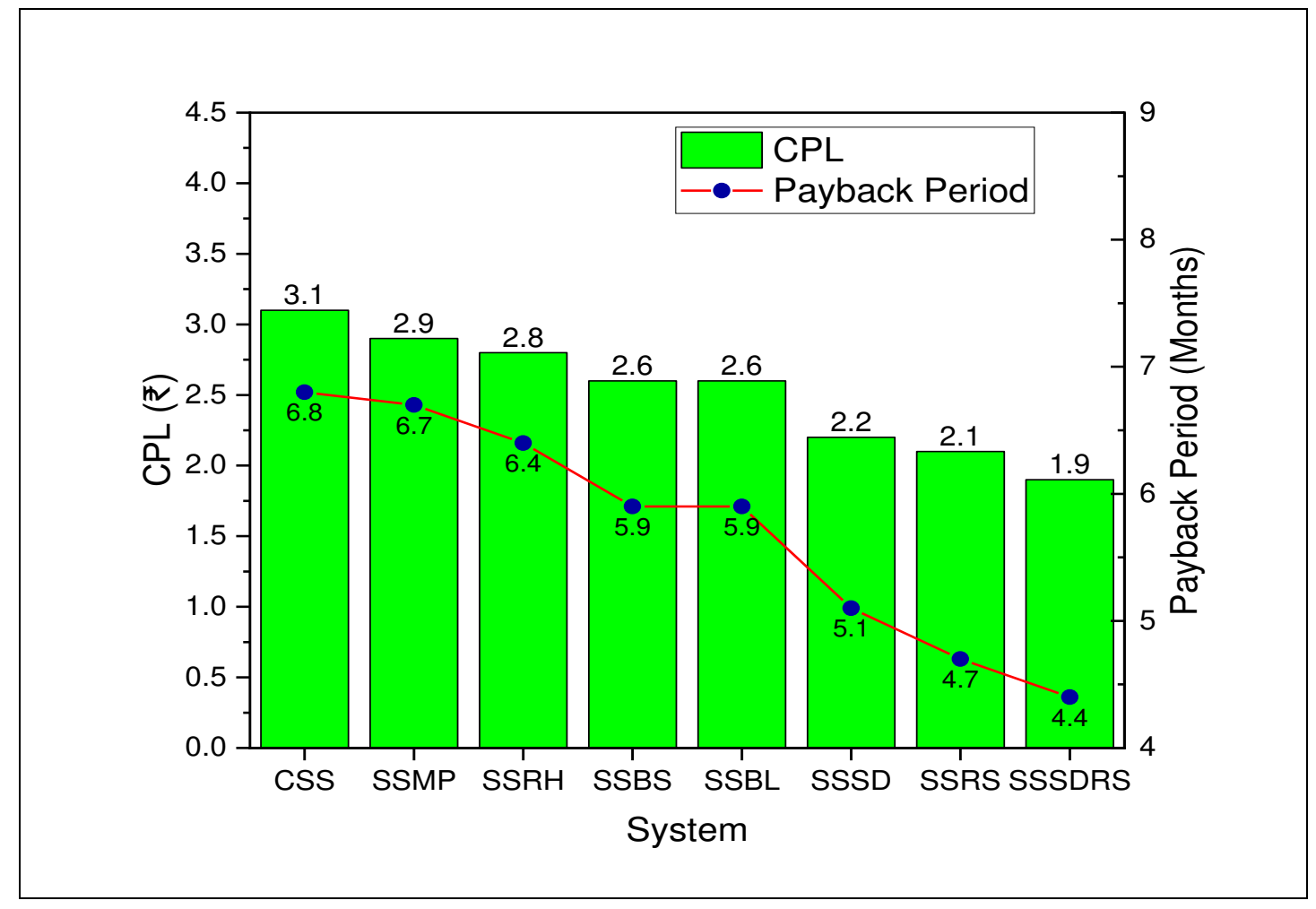

Fig. 20. Outcomes of economic analysis.

575 The principal investment was considered by taking the amount of each part of the solar still according to the

576 Indian trade value. The capital cost was calculated by considering all the fabrication, maintenance and operation

577 costs. The cost-effectiveness of both the solar stills was estimated using economic analysis and listed in Table 2.

578 From Table 2, it was observed that the cost per litre (CPL) was about₹ 3.1, ₹ 2.9, ₹ 2.8, ₹ 2.6, ₹ 2.6, ₹ 2.2, ₹ 2.1,

$579 ₹ 1.9$ and the payback periods were about $6.8,6.7,6.4,5.9,5.9,5.1,4.7,4.4$ months for CSS, SSMP, SSRH,

580 SSBS, SSBL, SSSD, SSRS and SSSDRS, respectively. The outcomes of the economic analysis of current

581 research were plotted in Fig 20. The outcomes of the economic analysis were compared with existing literature and tabulated in Table 3 which infers that this research paves a way for the most economical approach to enhance productivity as the payback period and cost per litre is the lowest in this research. As a whole, the inclusion of low-cost and eco-friendly natural materials in the absorber basin and condensing glass plate is economically viable and sustainable.

Table 2. Parameters and outcomes of Economic Analysis.

\begin{tabular}{|c|c|c|c|c|c|c|c|c|}
\hline Parameters & CSS & SSMP & SSRH & SSBS & SSBL & SSSD & SSRS & SSSDRS \\
\hline P. I & ₹ 9000 & ₹ 9200 & ₹ 9200 & ₹ 9200 & ₹ 9200 & ₹ 9200 & ₹ 9200 & ₹ 9400 \\
\hline I (years) & 10 & 10 & 10 & 10 & 10 & 10 & 10 & 10 \\
\hline $\mathbf{i}$ & $15 \%$ & $15 \%$ & $15 \%$ & $15 \%$ & $15 \%$ & $15 \%$ & $15 \%$ & $15 \%$ \\
\hline
\end{tabular}




\begin{tabular}{|c|c|c|c|c|c|c|c|c|}
\hline CRF & 0.2 & 0.2 & 0.2 & 0.2 & 0.2 & 0.2 & 0.2 & 0.2 \\
\hline FAC & 1800 & 1840 & 1840 & 1840 & 1840 & 1840 & 1840 & 1880 \\
\hline SF & 88.8 & 90.78 & 90.78 & 90.78 & 90.78 & 90.78 & 90.78 & 92.76 \\
\hline MC & 270 & 276 & 276 & 276 & 276 & 276 & 276 & 282 \\
\hline AC & 1981.1 & 2025.2 & 2025.2 & 2025.2 & 2025.2 & 2025.2 & 2025.2 & 2069.2 \\
\hline CPL (₹) & $₹ 3.1$ & $₹ 2.9$ & $₹ 2.8$ & $₹ 2.6$ & $₹ 2.6$ & $₹ 2.2$ & ₹ 2.1 & ₹ 1.9 \\
\hline PBP (months) & 6.8 & 6.7 & 6.4 & 5.9 & 5.9 & 5.1 & 4.7 & 4.4 \\
\hline
\end{tabular}

Table 3. Comparison of viability with the available literature.

\begin{tabular}{|c|c|c|c|c|c|}
\hline \multirow{2}{*}{ Parameters } & Current Study & (Modi and & $\begin{array}{c}\text { (Suraparaju } \\
\text { and Natarajan }\end{array}$ & $\begin{array}{c}\text { (Nayi and } \\
\text { Modi 2020) }\end{array}$ & 2020) \\
& (SSSDRS) & Modi 2019) & 2021a) & & - \\
\hline CPL & $₹ 1.9 / \$ 0.025$ & $₹ 2.4$ & ₹ 2.1 & ₹ 2.65 & 2.30 years \\
\hline PBP & 4.4 months & 15 months & 8.3 months & 11.28 months \\
\hline
\end{tabular}

\section{Conclusions}

In this research, an experimental investigation of eight single slope solar stills had been evaluated at NIT

590 Puducherry, Karaikal, India. The single slope solar stills considered for the experimental assessment were; i)

591 Conventional Solar Still (CSS), ii) Solar Still with Molasses Powder (SSMP), iii) Solar Still with Rice Husk

592 (SSRH), iv) Solar Still with Sawdust (SSSD), v) Solar Still with Bamboo Straw (SSBS), vi) Solar Still with

593 Banana Leaf Stem (SSBL) and vii) Solar Still with Rice Straw (SSRS) and viii) Solar Still with Sawdust and

594 Rice Straw (SSSDRS). The conclusions made from the current research were as following,

- The inclusion of Molasses Powder, Rice Huskand Sawdust in the absorber basin augmentedthe evaporation rate of seawater and thus the freshwater productivity was enhanced compared to CSS. The respective increase in the water temperature with the inclusion of these materials was about $3 \%$.

- The glass cover cooling was significantly enhanced by Bamboo Straw, Banana Leaf Stem and Rice Straw which augmented the freshwater productivity compared to CSS. The respective decrease in the glass cover temperature with the inclusion of these materials was about $40 \%$.

- The enhancement of evaporation and condensation rates by using the sawdust and rice straw simultaneously in the solar still resulted in a notable enhancement of productivity by $62.88 \%$. 
- The productivities of CSS, SSMP, SSRH, SSSD, SSBS, SSBL and SSRS were about $2250 \mathrm{~mL} / \mathrm{m}^{2}$, $2383 \mathrm{~mL} / \mathrm{m}^{2}, 2467 \mathrm{~mL} / \mathrm{m}^{2}, 3033 \mathrm{~mL} / \mathrm{m}^{2}, 2700 \mathrm{~mL} / \mathrm{m}^{2}, 2683 \mathrm{~mL} / \mathrm{m}^{2}$, and $3367 \mathrm{~mL} / \mathrm{m}^{2}$, respectively.

- The SSSD had a comparatively better evaporation rate and 34.81\% higher yield than CSS. Besides, SSRS had a comparatively better condensation rate and a 51.88\% higher yield than CSS.

- Later, the combination of sawdust (SD) and rice straw (RS) was investigated for combined enhancement of evaporation and condensation. The solar still with sawdust and rice straw (SSSDRS) showed a $62.88 \%$ improvement in productivity with $3633 \mathrm{~mL} / \mathrm{m}^{2}$ when compared to CSS.

- The overall thermal efficiencies of the CSS, SSMP, SSRH, SSSD, SSBS, SSBL, SSRS and SSSDRS were about $36.17 \%, 38.32 \%, 39.96 \% .48 .77 \%, 43.41 \%, 43.41 \%, 54.13 \%$ and $59.68 \%$, respectively.

- The economic analysis of the eight solar stills was assessed andthe cost of production per litre of freshwater was about ₹ 3.1 , ₹ 2.9 , ₹ 2.8 , ₹ 2.6 , ₹ 2.6 , ₹ 2.2 , ₹ 2.1 , ₹ 1.9 and the payback periods were about 6.8, 6.7, 6.4, 5.9, 5.9, 5.1, 4.7, 4.4 months for CSS, SSMP, SSRH, SSBS, SSBL, SSSD, SSRS and SSSDRS, respectively.

It has been concluded from the above observations that the Solar Still with Sawdust and Rice Straw(SSSDRS) had enhanced the evaporation and condensation rate simultaneously when compared to all other considered cases. Also, the potable water yield from the SSSDRS was comparatively better than all other considered cases. The economic analysis also evidenced that the SSSDRS was economically viable. From the above inferences, it can be concluded that SSSDRS has a promising capability to desalinate the seawater in an economic way and without causing any environmental pollution. Also, this work can be extended with other natural fibres with potential physio-thermal properties for enhancing the evaporation as well as condensation rate.

\section{$\underline{\text { Declarations }}$}

Ethics approval and consent to participate: Not applicable

Consent for Publication: Not applicable

Availability of data and materials:Datasets related to this research article can be found at http://dx.doi.org/10.17632/4s875xzmx8.1 an open-source online data repository hosted at Mendeley Data (Suraparaju and Natarajan 2021c)

Competing interests: The authors declare that they have no competing interests.

Funding: Not applicable

\section{CRediT authorship contribution statement:}


632 Sendhil Kumar Natarajan: Conceptualization, Validation, Resources, Writing - Review \& Editing, Supervision,

633 Project administration.

634 Subbarama Kousik Suraparaju:Conceptualization, Formal analysis, Investigation, Data Curation, Visualization,

635 Writing - Original Draft.

636 Rajvikram Madurai Elavarasan: Validation, Writing - Review \& Editing.

637 Rishi Pugazhendhi: Formal Analysis, Writing - Review \& Editing.

638 Eklas Hossain: Writing - Review \& Editing.

\section{References}

640 Agboola OP, Atikol U, Assefi H (2015) Feasibility assessment of basin solar stills. Int J Green Energy 12:139147. https://doi.org/10.1080/15435075.2014.889006

642 Akash BA, Mohsen MS, Nayfeh W (2000) Experimental study of the basin type solar still under local climate conditions. Energy Convers Manag 41:883-890. https://doi.org/10.1016/s0140-6701(00)93188-6

644 Al-Nimr MA, Al-Ammari WA (2016) A novel hybrid PV-distillation system. Sol Energy 135:874-883. https://doi.org/10.1016/j.solener.2016.06.061

646 Arunkumar T, Jayaprakash R, Denkenberger D, et al (2012) An experimental study on a hemispherical solar still. Desalination 286:342-348. https://doi.org/10.1016/j.desal.2011.11.047

Assis FS, Margem FM, Cordeiro TC, et al (2015) Photoacoustic thermal characterization of banana fibers. In: Materials Research. Universidade Federal de Sao Carlos, pp 240-245

Attia MEH, Driss Z, Kabeel AE, et al (2021a) Phosphate bags as energy storage materials for enhancement of solar still performance. Environ Sci Pollut Res

Attia MEH, Kabeel AE, Abdelgaied M, et al (2021b) Enhancement of hemispherical solar still productivity using iron, zinc and copper trays. Sol Energy 216:295-302. https://doi.org/10.1016/j.solener.2021.01.038

Balachandran GB, David PW, Rajendran G, et al (2020) Investigation of performance enhancement of solar still incorporated with Gallus gallus domesticus cascara as sensible heat storage material. Environ Sci Pollut Res. https://doi.org/10.1007/s11356-020-10470-3

Bello RS, Onilude MA (2017) Characterization of Sawdust Produced From Circular, Chain and Band Sawing Machines. 1:21-29. https://doi.org/10.11648/j.be.20170101.14

Bhargva M, Yadav A (2019) Productivity augmentation of single-slope solar still using evacuated tubes, heat 
662 Chamkha AJ, Rufuss DDW, Kabeel AE, et al (2020) Augmenting the potable water produced from single slope 663 solar still using CNT-doped paraffin wax as energy storage: an experimental approach. J Brazilian Soc 664 Mech Sci Eng 42:1-10. https://doi.org/10.1007/s40430-020-02703-w

665 Costes JP, Evrard A, Biot B, et al (2017) Thermal conductivity of straw bales: Full size measurements 666 considering the direction of the heat flow. Buildings 7:. https://doi.org/10.3390/buildings7010011

667 Dev R, Abdul-Wahab SA, Tiwari GN (2011) Performance study of the inverted absorber solar still with water 668 depth and total dissolved solid. Appl Energy 88:252-264. https://doi.org/10.1016/j.apenergy.2010.08.001

El-gazar EF, Zahra WK, Hassan H, Rabia SI (2021) Fractional modeling for enhancing the thermal performance of conventional solar still using hybrid nanofluid : Energy and exergy analysis. Desalination 503:114847. https://doi.org/10.1016/j.desal.2020.114847

673

El M, Attia H, Kabeel AE, Abdelgaied M (2021) Optimal concentration of El Oued sand grains as energy storage materials for enhancement of hemispherical distillers performance. J Energy Storage 36:102415. https://doi.org/10.1016/j.est.2021.102415

Elango T, Kannan A, Kalidasa Murugavel K (2015) Performance study on single basin single slope solar still with different water nanofluids. Desalination 360:45-51. https://doi.org/10.1016/j.desal.2015.01.004

Elmaadawy K, Kandeal AW, Khalil A, et al (2021) Performance improvement of double slope solar still via combinations of low cost materials integrated with glass cooling. Desalination 500:114856. https://doi.org/10.1016/j.desal.2020.114856

Gad HE, Shams El-Din S, Hussien AA, Ramzy K (2015) Thermal analysis of a conical solar still performance: An experimental study. Sol Energy 122:900-909. https://doi.org/10.1016/j.solener.2015.10.016

Ghaly AE, Zhang Y, Li B toc) Physical Properties of Rice Residues as Affected by Variety and Climatic and Cultivation Onditions in Three Continents. Am J Appl Sci 2012:1757-1768. https://doi.org/10.3844/ajassp.2012.1757.1768

Hassan H, Abo-Elfadl S (2017) Effect of the condenser type and the medium of the saline water on the performance of the solar still in hot climate conditions. Desalination 417:60-68. https://doi.org/10.1016/j.desal.2017.05.014 computed tomography and backscattered electron imaging. Wood Sci Technol 51:11-27. https://doi.org/10.1007/s00226-016-0865-6

Jafari Mosleh H, Mamouri SJ, Shafii MB, Hakim Sima A (2015) A new desalination system using a 

99:141-150. https://doi.org/10.1016/j.enconman.2015.04.028

694 Jagannadha Rao PVK, Das M, Das \& SK (2008) Thermophysical Properties of Sugarcane, Palmyra Palm, and Date-palm Granular Jaggery. Int J Food Prop 11:876-886. https://doi.org/10.1080/10942910701671281

Jani HK, Modi K V. (2019) Experimental performance evaluation of single basin dual slope solar still with circular and square cross-sectional hollow fins. Sol Energy 179:186-194. https://doi.org/10.1016/j.solener.2018.12.054

Judawisastra H, Sitohang RDR, Rosadi MS (2017) Water absorption and tensile strength degradation of Petung

Kabeel AE, Abdelgaied M (2016) Improving the performance of solar still by using PCM as a thermal storage medium under Egyptian conditions. Desalination. https://doi.org/10.1016/j.desal.2016.01.006

Kabeel AE, El-Maghlany WM, Abdelgaied M, Abdel-Aziz MM (2020) Performance enhancement of pyramidshaped solar stills using hollow circular fins and phase change materials. J Energy Storage 31:101610. https://doi.org/10.1016/j.est.2020.101610

Kabeel AE, Khairat Dawood MM, Ramzy K, et al (2019a) Enhancement of single solar still integrated with solar dishes: An experimental approach. Energy Convers Manag 196:165-174. https://doi.org/10.1016/j.enconman.2019.05.112

Kabeel AE, Manokar AM, Sathyamurthy R, et al (2019b) A review on different design modifications employed in inclined solar still for enhancing the productivity. J Sol Energy Eng Trans ASME 141:1-10. https://doi.org/10.1115/1.4041547

Kabeel AE, Sathyamurthy R, Sharshir SW, et al (2019c) Effect of water depth on a novel absorber plate of

716 Kalita P, Clifford MJ, Jiamjiroch K, et al (2013) Characterization and analysis of thermal response of rice husk for gasification applications. In: Journal of Renewable and Sustainable Energy. p 013119

718 Khalifa AJN, Hamood AM (2009) Effect of insulation thickness on the productivity of basin type solar stills : An experimental verification under local climate. Energy Convers Manag 50:2457-2461. https://doi.org/10.1016/j.enconman.2009.06.007 
solar still using agitation effect and external condenser. Desalination 399:198-202. https://doi.org/10.1016/j.desal.2016.09.006

Kumar S, Dubey A, Tiwari GN (2014) A solar still augmented with an evacuated tube collector in forced mode. Desalination 347:15-24. https://doi.org/10.1016/j.desal.2014.05.019

Mande AB, Manickam P (2019) Enhanced solar still productivity using transparent walls with an integral trough and organic porous absorber material. Int J Green Energy 16:211-227. https://doi.org/10.1080/15435075.2018.1549995

Manokar AM, Ravishankar MV, Kabeel AE (2020) Enhancement of potable water production from an inclined photovoltaic panel absorber solar still by integrating with flat - plate collector. Environ Dev Sustain 22:4145-4167. https://doi.org/10.1007/s10668-019-00376-7

Modi K V., Modi JG (2019) Performance of single-slope double-basin solar stills with small pile of wick materials. Appl Therm Eng 149:723-730. https://doi.org/10.1016/j.applthermaleng.2018.12.071

Morad MM, El-Maghawry HAM, Wasfy KI (2015) Improving the double slope solar still performance by using flat-plate solar collector and cooling glass cover. Desalination 373:1-9. https://doi.org/10.1016/j.desal.2015.06.017

Mounika M, Ramaniah K, Ratna Prasad A V, et al (2012) Thermal Conductivity Characterization of Bamboo Fiber Reinforced Polyester Composite. J Mater Environ Sci 3:1109-1116

Muthu Manokar A, Kalidasa Murugavel K, Esakkimuthu G (2014) Different parameters affecting the rate of evaporation and condensation on passive solar still - A review. Renew Sustain Energy Rev 38:309-322. https://doi.org/10.1016/j.rser.2014.05.092

Nagarajan PK, El-Agouz SA, Harris HS, et al (2017) Analysis of an inclined solar still with baffles for improving the yield of fresh water. Process Saf Environ Prot 105:326-337. https://doi.org/10.1016/j.psep.2016.11.018

Nayi KH, Modi K V. (2020) Effect of cost-free energy storage material and saline water depth on the performance of square pyramid solar still: a mathematical and experimental study. J Therm Anal Calorim.

748 Omara ZM, Hamed MH, Kabeel AE (2011) Performance of finned and corrugated absorbers solar stills under Egyptian conditions. Desalination 277:281-287. https://doi.org/10.1016/j.desal.2011.04.042 

nanofluids in stepped solar still. J Therm Anal Calorim 138:3175-3182. https://doi.org/10.1007/s10973019-08346-x

Patel SK, Modi K V. (2020) Techniques to improve the performance of enhanced condensation area solar still: A critical review. J Clean Prod 122260. https://doi.org/10.1016/j.jclepro.2020.122260

Pounraj P, Winston DP, Kabeel AE, et al (2018) Experimental investigation on Peltier based hybrid PV / T active solar still for enhancing the overall performance. Energy Convers Manag 168:371-381. https://doi.org/10.1016/j.enconman.2018.05.011

Prakash P, Velmurugan V (2015) Parameters influencing the productivity of solar stills - A review. Renew Sustain Energy Rev 49:585-609. https://doi.org/10.1016/j.rser.2015.04.136

Rabhi K, Nciri R, Nasri F, et al (2017) Experimental performance analysis of a modified single-basin singleslope solar still with pin fins absorber and condenser. Desalination 416:86-93. https://doi.org/10.1016/j.desal.2017.04.023

Raj G, Prabhansu D, Kumar R, et al (2020) Experimental study of solar still augmented with low-cost energy absorbing and releasing materials. Energy Sources, Part A Recover Util Environ Eff 42:56-65. https://doi.org/10.1080/15567036.2019.1587054

Reddy KS, Sharon H, Krithika D, Philip L (2018) Performance, water quality and enviro-economic investigations on solar distillation treatment of reverse osmosis reject and sewage water. Sol Energy 173:160-172. https://doi.org/10.1016/j.solener.2018.07.033

Saadi Z, Rahmani A, Lachtar S, Soualmi H (2018) Performance evaluation of a new stepped solar still under the desert climatic conditions. Energy Convers Manag 171:1749-1760. https://doi.org/10.1016/j.enconman.2018.06.114

Sampathkumar K, Arjunan T V., Senthilkumar P (2013) The experimental investigation of a solar still coupled with an evacuated tube collector. Energy Sources, Part A Recover Util Environ Eff 35:261-270. https://doi.org/10.1080/15567036.2010.511426

Sathish Kumar TR, Jegadheeswaran S, Chandramohan P (2019) Performance investigation on fin type solar still

780 Sathyamurthy R, El-Agouz SA, Dharmaraj V (2015) Experimental analysis of a portable solar still with evaporation and condensation chambers. Desalination 367:180-185. 
Sathyamurthy R, Kabeel AE, Balasubramanian M, et al (2020) Experimental study on enhancing the yield from stepped solar still coated using fumed silica nanoparticle in black paint. Mater Lett 272:127873. https://doi.org/10.1016/j.matlet.2020.127873

Sengphet KKD, Sato T, Ahmad Fauzi MN, Othman R (2014) Porous ceramic bodies using banana stem waste as a pore-forming agent. In: Advanced Materials Research. Trans Tech Publications Ltd, pp 131-136

Sharma B, Gatóo A, Bock M, Ramage M (2015) Engineered bamboo for structural applications. Constr Build Mater 81:66-73. https://doi.org/10.1016/j.conbuildmat.2015.01.077

Sharon H, Reddy KS (2015) A review of solar energy driven desalination technologies. Renew Sustain Energy Rev 41:1080-1118. https://doi.org/10.1016/j.rser.2014.09.002

Sharshir SW, Kandeal AW, Ismail M, et al (2019) Augmentation of a pyramid solar still performance using evacuated tubes and nanofluid: Experimental approach. Appl Therm Eng 160:113997. https://doi.org/10.1016/j.applthermaleng.2019.113997

Sharshir SW, Peng G, Elsheikh AH, et al (2018) Energy and exergy analysis of solar stills with micro/nano particles: A comparative study. Energy Convers Manag 177:363-375. https://doi.org/10.1016/j.enconman.2018.09.074

Sharshir SW, Peng G, Yang N, et al (2016) A hybrid desalination system using humidification-dehumidification and solar stills integrated with evacuated solar water heater. Energy Convers Manag 124:287-296. https://doi.org/10.1016/j.enconman.2016.07.028

Shehata AI, Kabeel AE, Khairat Dawood MM, et al (2020) Enhancement of the productivity for single solar still

804 Singh HN, Tiwari GN (2004) Monthly performance of passive and active solar stills for different Indian climatic conditions. Desalination 168:145-150. https://doi.org/10.1016/j.desal.2004.06.180

806 Sleiti AK, Al-Ammari WA, Al-Khawaja M (2021) Integrated novel solar distillation and solar single-effect absorption systems. Desalination 507:115032. https://doi.org/10.1016/j.desal.2021.115032

808 Sleiti AK, Al-Ammari WA, Al-Khawaja M (2020) A novel solar integrated distillation and cooling system 809 Design and analysis. Sol Energy 206:68-83. https://doi.org/10.1016/j.solener.2020.05.107

810 Suraparaju SK, Natarajan SK (2021a) Experimental investigation of single-basin solar still using solid staggered 811 fins inserted in paraffin wax PCM bed for enhancing productivity. Environ Sci Pollut Res 28:20330- 
813 Suraparaju SK, Natarajan SK (2020) Performance analysis of single slope solar desalination setup with natural

814 fiber. Desalin Water Treat 193:64-71. https://doi.org/10.5004/dwt.2020.25679

815 Suraparaju SK, Natarajan SK (2021b) Productivity enhancement of single-slope solar still with novel bottom

816 finned absorber basin inserted in phase change material (PCM): techno-economic and enviro-economic analysis. Environ Sci Pollut Res 1-22. https://doi.org/10.1007/s11356-021-13495-4

818 Suraparaju SK, Natarajan SK (2021c) Solar Still - Combined Evaporation and Condensation with Eco-Friendly

819 Materials. Mendeley Data V1:. https://doi.org/10.17632/4S875XZMX8.1

820 Suraparaju SK, Sampathkumar A, Natarajan SK (2021) Experimental and economic analysis of energy storage based single - slope solar still with hollow - finned absorber basin. Heat Transf 1-22. https://doi.org/10.1002/htj.22136

Tabrizi FF, Dashtban M, Moghaddam H, Razzaghi K (2010) Effect of water flow rate on internal heat and mass transfer and daily productivity of a weir-type cascade solar still. Desalination 260:239-247. https://doi.org/10.1016/j.desal.2010.03.037

Taheri Mousavi SM, Egelioglu F, Ilkan M (2020) Experimental and numerical study of the effect of various design configurations on the thermal performance of solar still desalination. Energy Sources, Part A Recover Util Environ Eff 00:1-15. https://doi.org/10.1080/15567036.2020.1826018

Thirugnanasambandam M, Iniyan S, Goic R (2010) A review of solar thermal technologies. Renew Sustain Energy Rev 14:312-322. https://doi.org/10.1016/j.rser.2009.07.014

Tiwari AK, Tiwari GN (2006) Effect of water depths on heat and mass transfer in a passive solar still: in summer climatic condition. Desalination 195:78-94. https://doi.org/10.1016/j.desal.2005.11.014

Tiwari GN, Sahota L (2017) Review on the energy and economic efficiencies of passive and active solar distillation systems. Desalination 401:151-179. https://doi.org/10.1016/j.desal.2016.08.023

Tripathi R, Tiwari GN (2005) Effect of water depth on internal heat and mass transfer for active solar distillation. Desalination 173:187-200. https://doi.org/10.1016/j.desal.2004.08.032

Velmurugan V, Deenadayalan CK, Vinod H, Srithar K (2008a) Desalination of effluent using fin type solar still. Energy 33:1719-1727. https://doi.org/10.1016/j.energy.2008.07.001

Velmurugan V, Gopalakrishnan M, Raghu R, Srithar K (2008b) Single basin solar still with fin for enhancing productivity. Energy Convers Manag 49:2602-2608. https://doi.org/10.1016/j.enconman.2008.05.010 

solar stills with mini solar pond. Desalination 249:902-909. https://doi.org/10.1016/j.desal.2009.06.070

843 Xevgenos D, Moustakas K, Malamis D, Loizidou M (2016) An overview on desalination \& sustainability:

844 renewable energy-driven desalination and brine management. Desalin Water Treat 57:2304-2314.

$845 \quad$ https://doi.org/10.1080/19443994.2014.984927

846 Zanganeh P, Goharrizi AS, Ayatollahi S, et al (2020) Efficiency improvement of solar stills through wettability

$847 \quad$ alteration of the condensation surface: An experimental study. Appl Energy 268:114923.

$848 \quad$ https://doi.org/10.1016/j.apenergy.2020.114923

849 Zanganeh P, Goharrizi AS, Ayatollahi S, Feilizadeh M (2019) Productivity enhancement of solar stills by nano850 coating of condensing surface. Desalination 454:1-9. https://doi.org/10.1016/j.desal.2018.12.007 